\title{
Chemical Ionization of Phenyl $n$-Propyl Ether and Methyl Substituted Analogs: Propene Loss Initiated by Competing Proton Transfer to the Oxygen Atom and the Aromatic Ring
}

\author{
Bogdan Bogdanov, Henri E. K. Matimba, Steen Ingemann, and \\ Nico M. M. Nibbering \\ Institute of Mass Spectrometry, University of Amsterdam, Nieuwe Achtergracht 129, 1018 WS Amsterdam, \\ The Netherlands
}

\begin{abstract}
The mechanism of propene loss from protonated phenyl $n$-propyl ether and a series of mono-, di-, and trimethylphenyl $n$-propyl ethers has been examined by chemical ionization (CI) mass spectrometry in combination with tandem mass spectrometry experiments. The role of initial proton transfer to the oxygen atom and the aromatic ring, respectively, has been probed with the use of deuterated $\mathrm{CI}$ reagents, $\mathrm{D}_{2} \mathrm{O}, \mathrm{CD}_{3} \mathrm{OD}$, and $\mathrm{CD}_{3} \mathrm{CN}$ (given in order of increasing proton affinity), in combination with deuterium labeling of the $\beta$ position of the $n$-propyl group or the phenyl ring. The metastable $[\mathrm{M}+\mathrm{D}]^{+}$ions of phenyl $n$-propyl ether-formed with $\mathrm{D}_{2} \mathrm{O}$ as the $\mathrm{CI}$ reagent-eliminate $\mathrm{C}_{3} \mathrm{H}_{5} \mathrm{D}$ and $\mathrm{C}_{3} \mathrm{H}_{6}$ in a ratio of 10:90, which indicates that the added deuteron is incorporated to a minor extent in the expelled neutral species. In the experiments with $\mathrm{CD}_{3} \mathrm{OD}$ as the $\mathrm{CI}$ reagent, the ratio between the losses of $\mathrm{C}_{3} \mathrm{H}_{5} \mathrm{D}$ and $\mathrm{C}_{3} \mathrm{H}_{6}$ from the metastable $[\mathrm{M}+\mathrm{D}]^{+}$ions of phenyl $n$-propyl ether is 18:82, whereas the ratio becomes $27: 73$ with $\mathrm{CD}_{3} \mathrm{CN}$ as the reagent. A similar trend in the tendency to expel a propene molecule that contains the added deuteron is observed for the metastable $[\mathrm{M}+\mathrm{D}]^{+}$ions of phenyl $n$-propyl ether labeled at the $\beta$ position of the alkyl group. Incorporation of a hydrogen atom that originates from the aromatic ring in the expelled propene molecule is of negligible importance as revealed by the minor loss of $\mathrm{C}_{3} \mathrm{H}_{5} \mathrm{D}$ from the metastable $[\mathrm{M}+\mathrm{H}]^{+}$ions of $\mathrm{C}_{6} \mathrm{D}_{5} \mathrm{OCH}_{2} \mathrm{CH}_{2} \mathrm{CH}_{3}$ irrespective of whether $\mathrm{H}_{2} \mathrm{O}, \mathrm{CH}_{3} \mathrm{OH}$, or $\mathrm{CH}_{3} \mathrm{CN}$ is the $\mathrm{CI}$ reagent. The combined results for the $[\mathrm{M}+\mathrm{D}]^{+}$ions of phenyl n-propyl ether and deuterium-labeled analogs are suggested to be in line with a model that assumes that propene loss occurs not only from species formed by deuteron transfer to the oxygen atom, but also from ions generated by deuteron transfer to the ring. This is substantiated by the results for the methyl-substituted ethers, which reveal that the position as well as the number of methyl groups bonded to the ring exert a marked effect on the relative importances of the losses of $\mathrm{C}_{3} \mathrm{H}_{5} \mathrm{D}$ and $\mathrm{C}_{3} \mathrm{H}_{6}$ from the metastable $[\mathrm{M}+\mathrm{D}]^{+}$ ions of the unlabeled methyl-substituted species. (J Am Soc Mass Spectrom 1996, 7, 639-652)
\end{abstract}

$\mathrm{T}$ The determination of the site of protonation of polyfunctional organic molecules in the gas phase has received continuing interest from a theoretical as well as an experimental point of view [1-16]. This interest is related to the fundamental importance of site-specific proton affinities (PA) as well as the significance of proton transfer reactions that occur in the absence of solvent molecules and/or counterions [17-21]. The site of proton attachment is dependent, of course, not only on the proton affinities of the distinct sites, but also on the possible existence of energy barriers for transfer to the various positions within a

Address reprint requests to Professor Dr. N. M. M. Nibbering, Institute of Mass Spectrometry, University of Amsterdam, Nieuwe Achtergracht 129, 1018 WS Amsterdam, The Netherlands. given molecule [22-25]. In this respect, several reports indicate that proton transfer to the aromatic ring of a benzene compound substituted with a heteroatomcontaining functional group is often thermodynamically preferred over proton attachment to the substituent $[4,6,8,9,12,14,15]$. Nevertheless, protonation of the substituent is often more facile and can be the predominant-if not exclusive-reaction that occurs under typical chemical ionization (CI) conditions and with the use of methane or 2-methylpropane as the CI reagent $[3,12,14,15]$. This situation is exemplified by fluorobenzene, which is protonated readily at the heteroatom in the strongly exothermic reaction with $\mathrm{CH}_{5}^{+}$ irrespective of the fact that proton transfer to the ring is indicated to be thermodynamically more favorable $[12,15,26]$. Preferential proton transfer to the sub- 
stituent is reported to occur also for the strongly exothermic reaction between $\mathrm{CH}_{5}^{+}$and methyl phenyl ether [26], and a similar finding is reported for $\mathrm{CI}$ of this ether with water as the reagent $[3,27]$. In the latter system, the occurrence of proton transfer to the oxygen atom was inferred mainly on the basis of the occurrence of a slow exchange of one hydrogen atom from the ring of the protonated species with a deuterium atom if $\mathrm{D}_{2} \mathrm{O}$ were present in the $\mathrm{CI}$ ion source $[3,27]$. Proton transfer to the aromatic ring of methyl phenyl ether is reported, however, to become more pronounced if a $\mathrm{CI}$ reagent with a higher proton affinity than water is used [26, 27]. With $\mathrm{CH}_{3} \mathrm{CH}_{2} \mathrm{OD}$, for example, deuteron transfer to methyl phenyl ether leads to ions which exchange up to three hydrogen atoms from the ring with deuterium atoms from the CI reagent [27].

An understanding of the molecular properties that determine the regioselectivity of proton transfer reactions to polyfunctional compounds in the gas phase is also of prime importance for the use of CI mass spectrometry as a method for structure elucidation [1]. In this respect, the initial site of protonation is often reflected directly in the ensuing dissociations of the protonated species. For example, methane $\mathrm{CI}$ of a series of aromatic compounds substituted with an oxygen- and a nitrogen-atom-containing functionality $\left[\mathrm{XCH}_{2} \mathrm{C}_{6} \mathrm{H}_{4} \mathrm{CH}_{2} \mathrm{Y} ; \mathrm{X}=\mathrm{OH}\right.$ and $\mathrm{OCH}_{3} ; \mathrm{Y}=\mathrm{NH}_{2}$ and $\mathrm{N}\left(\mathrm{CH}_{3}\right)_{2}$ ] is reported to involve competing proton transfer to these heteroatoms followed by the losses of $\mathrm{XH}$ and $\mathrm{YH}$ in a ratio that was concluded to reflect the extent of protonation of the two sites [28-30]. A more complex situation arises for protonated bifunctional species that dissociate by a single pathway that involves partial incorporation of the added proton in the expelled neutral species. This situation applies to propene loss from the $[\mathrm{M}+\mathrm{H}]^{+}$ions of phenyl $n$-propyl ether formed in a CI ion source with molecular hydrogen, methane, or 2-methylpropane as the reagent [31-33]. As indicated by the reported studies [31, 32], the proton added to the ether is retained not only in the ionic product, but also to some extent in the propene molecule expelled from the $[\mathrm{M}+\mathrm{H}]^{+}$ions. This finding has been suggested [32,33] to be a result of a process that involves initial proton transfer to the oxygen atom of the ether function followed by cleavage of the bond between the oxygen atom and the $\alpha$-carbon atom of the $n$-propyl group concomitant with a 1,2-hydride shift in the evolving primary carbenium ion [34]. The thus formed ion-neutral complex [35, 36] of a phenol molecule and a secondary carbenium ion was considered to react subsequently by a partially reversible proton transfer, which was held responsible for the occurrence of interchange between the added proton and the hydrogen atoms of the $n$-propyl group in the parent compound.

Notwithstanding the reported studies of propene loss from protonated phenyl $n$-propyl ether [31, 32], competing proton transfer to the ring and the oxygen atom can be expected to occur under CI conditions and give rise to different ions. In view of the results for protonation of the simplest aromatic ether, methyl phenyl ether [3, 26, 27], the related extent of proton transfer to the various sites of the phenyl $n$-propyl ether is likely to depend on the nature of the CI gas. These considerations prompted us to examine whether proton transfer to the different sites in phenyl $n$-propyl ether occurs under $\mathrm{CI}$ conditions and whether the different ionic species participate in the overall process that leads to propene loss. To achieve this insight we decided to use a series of reagents with a different proton affinity and, in addition, to perturb the possible interplay between proton transfer to the ring and the oxygen atom by the introduction of methyl groups at the aromatic ring. The deuteronated reagents, $\mathrm{D}_{2} \mathrm{O}$, $\mathrm{CD}_{3} \mathrm{OD}$, and $\mathrm{CD}_{3} \mathrm{CN}$ (listed in order of increasing proton affinity) [37], were chosen to determine the fate of the deuteron transferred in the initial step with respect to the extent of incorporation in the expelled propene molecule. Furthermore, a series of deuteriumlabeled ethers was prepared to obtain more insight into the possible interchange of hydrogen-deuterium atoms from the different sites prior to the expulsion of propene.

\section{Experimental}

The chemical ionization (CI) spectra and the massanalyzed ion kinetic energy spectra (MIKES) [38] were recorded with the use of a Fisons (Manchester, UK) VG ZAB-HFqQ reverse geometry double-focusing quadrupole hybrid mass spectrometer $[39,40]$. The CI reagents $\left(D_{2} O, C D_{3} O D\right.$, or $\left.C_{3} C N\right)$ were mixed with phenyl n-propyl ether or one of the methyl-substituted compounds in a volume ratio of 9:1. The binary chemical sample was introduced into a combined electron ionization-chemical ionization (EI/CI) source through a heated septum inlet system (temperature $\approx 130^{\circ} \mathrm{C}$ ) until the pressure was in the range of $10^{-4}-10^{-3} \mathrm{~Pa}$ as measured by an ionization gauge placed in a side arm to the entrance of the diffusion pump situated beneath the ion source housing. The ion source parameters were: electron energy $70 \mathrm{eV}$, temperature $150-200{ }^{\circ} \mathrm{C}$, ion repeller potential $0 \mathrm{~V}$, and acceleration voltage $8 \mathrm{kV}$.

The phenyl $n$-propyl ether and the methyl-substituted analogs (3- and 4-methylphenyl $n$-propyl ether, 2,6- and 3,5-dimethylphenyl $n$-propyl ether as well as 2,4,6-trimethylphenyl $n$-propyl ether) were prepared by reacting the sodium salt of the appropriate $\left(\mathrm{CH}_{3}\right)_{n} \mathrm{C}_{6} \mathrm{H}_{5-n} \mathrm{O}^{-}$ion $(n=0-3)$ with $\mathrm{CH}_{3} \mathrm{CH}_{2} \mathrm{CH}_{2} \mathrm{Br}$ for a period of $24 \mathrm{~h}$ in a mixture of water and $\mathrm{N}, \mathrm{N}$-dimethylformamide (DMF) at a temperature of $50{ }^{\circ} \mathrm{C}$ [41]. The corresponding compounds labeled with two deuterium atoms at the $\beta$ position of the $n$-propyl group ( $>97 \% d_{2}$ ) were prepared likewise by reacting a given $\left(\mathrm{CH}_{3}\right)_{n} \mathrm{C}_{6} \mathrm{H}_{5-\mathrm{n}} \mathrm{O}^{-}$ion with $\mathrm{CH}_{3} \mathrm{CD}_{2} \mathrm{CH}_{2} \mathrm{Br}$. The $\mathrm{C}_{6} \mathrm{D}_{5} \mathrm{OCH}_{2} \mathrm{CH}_{2} \mathrm{CH}_{3}$ ether $\left(96 \% d_{5}\right.$ and $\left.4 \% d_{4}\right)$ 
was synthesized similarly by reacting $\mathrm{C}_{6} \mathrm{D}_{5} \mathrm{O}^{-}$with $\mathrm{CH}_{3} \mathrm{CH}_{2} \mathrm{CH}_{2} \mathrm{Br}$ in a mixture of deuterium oxide $\left(\mathrm{D}_{2} \mathrm{O}\right)$ and $\mathrm{DMF}$, which was dried prior to use. The ethers were purified by preparative gas chromatography (column: Reoplex 400, Geigy Company, Ltd., Manchester, UK; temperature $110-150^{\circ} \mathrm{C}$ ). The identity of the ethers was confirmed by ${ }^{1} \mathrm{H}$ NMR and the label content was determined by electron ionization (EI) mass spectrometry.

\section{Results}

In the previous studies concerned with propene loss from protonated phenyl $n$-propyl ether, molecular hydrogen, methane, and 2-methylpropane were used as the $\mathrm{CI}$ reagents [31,32]. With these $\mathrm{CI}$ gases, extensive fragmentation of the protonated ether occurred in the ion source and consequently only a minor amount of metastable $[M+D]^{+}$ions was generated if $C_{4}$ was the $C I$ reagent. A similar complication was observed under our experimental conditions with methane as the CI gas. It was decided, therefore, to use only CI reagents with a higher proton affinity than methane, which thus decreases the exothermicity of the deuteron transfer to the ethers. The reagents, $\mathrm{D}_{2} \mathrm{O}, \mathrm{CD}_{3} \mathrm{OD}$, and $\mathrm{CD}_{3} \mathrm{CN}$ were selected because they could be admitted to the ion source relatively easily together with the aromatic ethers. As anticipated, the conjugate Brønsted acids of the selected reagents proved to transfer a deuteron to the ethers relatively readily and form abundant stable (see Figure 1) as well as metastable $[\mathrm{M}+\mathrm{D}]^{+}$ions.

In line with the previous findings [31, 32], the [M+ $\mathrm{D}^{+}$ions of phenyl $n$-propyl ether expel on the microsecond time scale only propene, irrespective of whether $D_{2} \mathrm{O}, \mathrm{CD}_{3} \mathrm{OD}$, or $\mathrm{CD}_{3} \mathrm{CN}$ is the $\mathrm{CI}$ reagent, and a similar behavior is observed for the methyl-substituted species included in this study. In the experiments with $\mathrm{D}_{3} \mathrm{O}^{+}$as the deuteron donor, the metastable $[\mathrm{M}+\mathrm{D}]^{+}$ions of phenyl $n$-propyl ether expel $\mathrm{C}_{3} \mathrm{H}_{5} \mathrm{D}$ and $\mathrm{C}_{3} \mathrm{H}_{6}$ with formation of $\mathrm{C}_{6} \mathrm{H}_{7} \mathrm{O}^{+}$ and $\mathrm{C}_{6} \mathrm{H}_{6} \mathrm{DO}^{+}$ions (see eq 1 ) in an abundance ratio of 10:90 (see Table 1). This ratio is essentially the same as reported previously on the basis of experiments with $\mathrm{CD}_{4}$ as the $\mathrm{CI}$ reagent, notwithstanding that deuteron transfer from $\mathrm{D}_{3} \mathrm{O}^{+}$to phenyl $n$-propyl ether is about $145 \mathrm{~kJ} \mathrm{~mol}^{-1}$ less exothermic than if $\mathrm{CD}_{5}^{+}$is the deuteron donor [37].

$$
\begin{aligned}
\mathrm{C}_{6} \mathrm{H}_{5} \mathrm{OCH}_{2} \mathrm{CH}_{2} \mathrm{CH}_{3} \frac{\mathrm{D}_{3} \mathrm{O}^{+}}{-\mathrm{D}_{2} \mathrm{O}} \\
{[\mathrm{M}+\mathrm{D}]^{+} \underset{\stackrel{90 \%}{\longrightarrow} \mathrm{C}_{6} \mathrm{H}_{6} \mathrm{DO}^{+}+\mathrm{C}_{3} \mathrm{H}_{6}}{\stackrel{10 \%}{\longrightarrow} \mathrm{C}_{6} \mathrm{H}_{7} \mathrm{O}^{+}+\mathrm{C}_{3} \mathrm{H}_{5} \mathrm{D}} }
\end{aligned}
$$

The replacement of $\mathrm{D}_{2} \mathrm{O}$ with $\mathrm{CD}_{3} \mathrm{OD}$ is expected to decrease the exothermicity of deuteron transfer to the
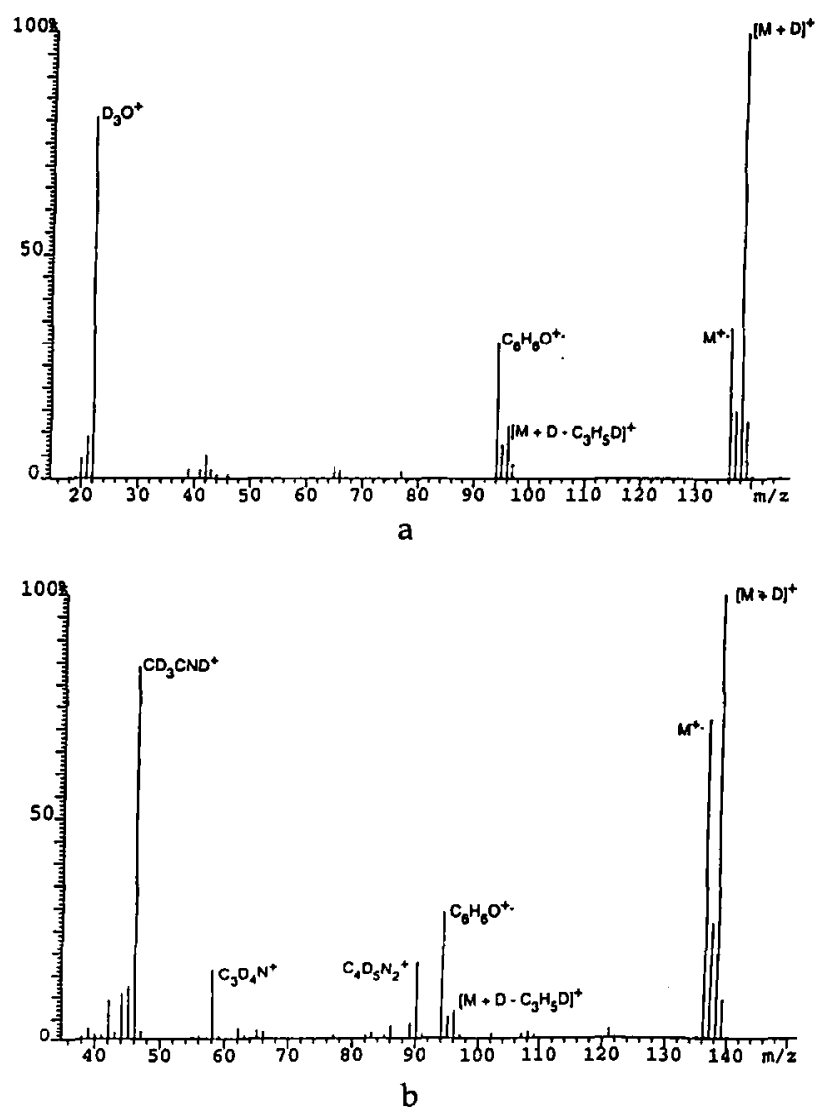

Figure 1. Chemical ionization mass spectra of phenyl n-propyl ether with (a) $D_{2} \mathrm{O}$ as the $\mathrm{CI}$ reagent with (b) $C D_{3} \mathrm{CN}$ as the reagent. The presence of peaks corresponding to the molecular ion of the phenyl $n$-propyl ether $(m / z 136)$ and the $\mathrm{C}_{6} \mathrm{H}_{6} \mathrm{O}^{+}$ product ion $(m / z 94)$ of propene loss from the $\mathrm{M}^{+\cdot}$ ion is in agreement with the relatively low pressure in the combined electron ionization/chemical ionization ion source (see also Experimental).

phenyl $n$-propyl ether by about $80 \mathrm{~kJ} \mathrm{~mol}^{-1}$ when the difference between the proton affinities of water $\left[\mathrm{PA}\left(\mathrm{H}_{2} \mathrm{O}\right)=679 \mathrm{~kJ} \mathrm{~mol}^{-1}\right]$ and methanol [PA $\left(\mathrm{CH}_{3} \mathrm{OH}\right)=761 \mathrm{~kJ} \mathrm{~mol}^{-1}$ ] is considered [37]. The metastable $[\mathrm{M}+\mathrm{D}]^{+}$ions of the unsubstituted ether formed in the reactions of the $\mathrm{CD}_{3} \mathrm{OD}_{2}^{+}$ions are observed to expel relatively more $\mathrm{C}_{3} \mathrm{H}_{5} \mathrm{D}$ as compared to the $[M+D]^{+}$ions generated with $\mathrm{D}_{2} \mathrm{O}$ as the $\mathrm{CI}$ reagent (see Table 1 ). This tendency is even more pronounced if $\mathrm{CD}_{3} \mathrm{CND}^{+}\left[\mathrm{PA}\left(\mathrm{CH}_{3} \mathrm{CN}\right)=788 \mathrm{~kJ}\right.$ $\left.\mathrm{mol}^{-1}\right][37]$ is the deuteron donor; that is, the $[\mathrm{M}+\mathrm{D}]^{+}$ ions formed with $\mathrm{CD}_{3} \mathrm{CN}$ as the $\mathrm{CI}$ reagent eliminate on the microsecond time scale $\mathrm{C}_{3} \mathrm{H}_{5} \mathrm{D}$ and $\mathrm{C}_{3} \mathrm{H}_{6}$ in a ratio of 27:73. A similar trend in the loss of propene that contains the added deuteron is observed for the phenyl $n$-propyl ether labeled with two deuterium atoms at the $\beta$ position. For example, the relative importance of the losses of $\mathrm{C}_{3} \mathrm{H}_{3} \mathrm{D}_{3}, \mathrm{C}_{3} \mathrm{H}_{4} \mathrm{D}_{2}$, and $\mathrm{C}_{3} \mathrm{H}_{5} \mathrm{D}$ from the metastable $[\mathrm{M}+\mathrm{D}]^{+}$ions of this labeled ether is 7:76:17 if $\mathrm{D}_{3} \mathrm{O}^{+}$is the deuteron donor (see eq 2). With $\mathrm{CD}_{3} \mathrm{CND}^{+}$as the deuteron donor, the $[M+D]^{+}$ions of the labeled phenyl $n$-propyl ether 
Table 1. Relative importances (\%) of the losses of $\mathrm{C}_{3} \mathrm{H}_{3} \mathrm{D}_{3}, \mathrm{C}_{3} \mathrm{H}_{4} \mathrm{D}_{2}, \mathrm{C}_{3} \mathrm{H}_{5} \mathrm{D}$, and $\mathrm{C}_{3} \mathrm{H}_{6}$ from the metastable $[\mathrm{M}+\mathrm{H}]^{+}$and $[\mathrm{M}+\mathrm{D}]^{+}$ions of phenyl $n$-propyl ether and deuterium-labeled analogs (see also text)

\begin{tabular}{|c|c|c|c|c|c|c|}
\hline \multirow{2}{*}{$\begin{array}{c}\text { Compound } \\
M\end{array}$} & \multirow{2}{*}{$\begin{array}{l}\text { Reactant } \\
\text { ion }\end{array}$} & \multirow{2}{*}{$\underset{\text { reagent }}{\mathrm{Cl}}$} & \multicolumn{4}{|c|}{ Importance of the loss of } \\
\hline & & & $\mathrm{C}_{3} \mathrm{H}_{3} \mathrm{D}_{3}$ & $\mathrm{C}_{3} \mathrm{H}_{4} \mathrm{D}_{2}$ & $\mathrm{C}_{3} \mathrm{H}_{5} \mathrm{D}$ & $\overline{\mathrm{C}_{3} \mathrm{H}_{6}}$ \\
\hline \multirow{3}{*}{$\mathrm{C}_{6} \mathrm{H}_{5} \mathrm{OCH}_{2} \mathrm{CH}_{2} \mathrm{CH}_{3}{ }^{\mathrm{b}}$} & {$[M+D]^{+}$} & $\overline{\mathrm{D}_{2} \mathrm{O}}$ & & & 10 & 90 \\
\hline & & $\mathrm{CD}_{3} \mathrm{OD}$ & & & 18 & 82 \\
\hline & & $\mathrm{CD}_{3} \mathrm{CN}$ & & & 27 & 73 \\
\hline \multirow{3}{*}{$\mathrm{C}_{6} \mathrm{H}_{5} \mathrm{OCH}_{2} \mathrm{CD}_{2} \mathrm{CH}_{3}{ }^{\mathrm{c}}$} & {$[M+D]^{+}$} & $\mathrm{D}_{2} \mathrm{O}$ & 7 & 76 & 17 & \\
\hline & & $\mathrm{CD}_{3} \mathrm{OD}$ & 19 & 70 & 11 & \\
\hline & & $\mathrm{CD}_{3} \mathrm{CN}$ & 21 & 67 & 12 & \\
\hline \multirow[t]{3}{*}{$\mathrm{C}_{6} \mathrm{D}_{6} \mathrm{OCH}_{2} \mathrm{CH}_{2} \mathrm{CH}_{3}^{\mathrm{d}}$} & {$[\mathrm{M}+\mathrm{H}]^{+}$} & $\mathrm{H}_{2} \mathrm{O}$ & & & 3 & 97 \\
\hline & & $\mathrm{CH}_{3} \mathrm{OH}$ & & & 2 & 98 \\
\hline & & $\mathrm{CH}_{3} \mathrm{CN}$ & & & 5 & 95 \\
\hline \multirow[t]{3}{*}{$\mathrm{C}_{6} \mathrm{D}_{5} \mathrm{OCH}_{2} \mathrm{CH}_{2} \mathrm{CH}_{3}^{\circ}$} & {$[M+D]^{+}$} & $\mathrm{D}_{2} \mathrm{O}$ & & & 13 & 87 \\
\hline & & $\mathrm{CD}_{3} \mathrm{OD}$ & & & 19 & 81 \\
\hline & & $\mathrm{CD}_{3} \mathrm{CN}$ & & & 30 & 70 \\
\hline
\end{tabular}

expel these neutral species in a ratio of $21: 67: 12$ as shown in Table 1.

$$
\begin{aligned}
\mathrm{C}_{6} \mathrm{H}_{5} \mathrm{OCH}_{2} \mathrm{CD}_{2} \mathrm{CH}_{3} \frac{\mathrm{D}_{3} \mathrm{O}^{+}}{-\mathrm{D}_{2} \mathrm{O}} \\
{[\mathrm{M}+\mathrm{D}]^{+} \stackrel{7 \%}{\stackrel{76 \%}{\longrightarrow} \mathrm{C}_{6} \mathrm{H}_{7} \mathrm{O}^{+}+\mathrm{C}_{3} \mathrm{H}_{3} \mathrm{D}_{3}} \underset{\mathrm{C}_{6} \mathrm{H}_{6} \mathrm{DO}^{+}+\mathrm{C}_{3} \mathrm{H}_{4} \mathrm{D}_{2}}{\stackrel{17 \%}{\longrightarrow}} \mathrm{C}_{6} \mathrm{H}_{5} \mathrm{D}_{2} \mathrm{O}^{+}+\mathrm{C}_{3} \mathrm{H}_{5} \mathrm{D} }
\end{aligned}
$$

The absence of $\mathrm{C}_{3} \mathrm{H}_{6}$ loss from the $[\mathrm{M}+\mathrm{D}]^{+}$ions of $\mathrm{C}_{6} \mathrm{H}_{5} \mathrm{OCH}_{2} \mathrm{CD}_{2} \mathrm{CH}_{3}$ indicates that extensive interchange between the hydrogen atoms from the aromatic ring and the deuterium atoms of the alkyl group does not occur prior to dissociation. This observation is further substantiated by the results of the experiments with the ring-labeled ether $\mathrm{C}_{6} \mathrm{D}_{5} \mathrm{OCH}_{2} \mathrm{CH}_{2} \mathrm{CH}_{3}$. For this ether, the $[\mathrm{M}+\mathrm{H}]^{+}$ions eliminate only minor amounts of $\mathrm{C}_{3} \mathrm{H}_{5} \mathrm{D}$ irrespective of whether water, methanol, or acetonitrile is used as the $\mathrm{Cl}$ reagent (see eq 3 and Table 1 ). In addition, the metastable $\left[\mathrm{M}+\mathrm{D}^{+}\right.$ ions of the ring-labeled ether expel $\mathrm{C}_{3} \mathrm{H}_{5} \mathrm{D}$ and $\mathrm{C}_{3} \mathrm{H}_{6}$ in a ratio that, for a given $\mathrm{CI}$ reagent, is close to the ratio obtained for the $[\mathrm{M}+\mathrm{D}]^{+}$ions of the unlabeled phenyl $n$-propyl ether.

$$
\begin{aligned}
\mathrm{C}_{6} \mathrm{D}_{5} \mathrm{OCH}_{2} \mathrm{CH}_{2} \mathrm{CH}_{3} \stackrel{\mathrm{H}_{3} \mathrm{O}^{+}}{-\mathrm{H}_{2} \mathrm{O}} \\
{[\mathrm{M}+\mathrm{H}]^{++} \underset{\stackrel{\sim 3 \%}{\longrightarrow} \mathrm{C}_{6} \mathrm{D}_{4} \mathrm{H}_{3} \mathrm{O}^{+}+\mathrm{C}_{3} \mathrm{H}_{5} \mathrm{D}}{\stackrel{\sim 97 \%}{\longrightarrow}} \mathrm{C}_{6} \mathrm{D}_{5} \mathrm{H}_{2} \mathrm{O}^{+}+\mathrm{C}_{3} \mathrm{H}_{6} }
\end{aligned}
$$

The introduction of one or more methyl groups on the phenyl ring in most instances has a profound effect on the distribution of the abundances of the product ions of the competing losses of propene molecules with up to three deuterium atoms. This holds in particular for the metastable $[\mathrm{M}+\mathrm{D}]^{+}$ions formed in the reactions of the $\mathrm{CD}_{3} \mathrm{OD}_{2}^{+}$or $\mathrm{CD}_{3} \mathrm{CND}^{+}$ions. For example, the metastable $[\mathrm{M}+\mathrm{D}]^{+}$ions of the 3-methylphenyl $n$ propyl ether eliminate $\mathrm{C}_{3} \mathrm{H}_{5} \mathrm{D}$ and $\mathrm{C}_{3} \mathrm{H}_{6}$ in a ratio that is close to that obtained for the unsubstituted species if $\mathrm{D}_{3} \mathrm{O}^{+}$is the deuteron donor (see Tables 1 and 2). By contrast, the loss of $\mathrm{C}_{3} \mathrm{H}_{5} \mathrm{D}$ is significantly less important for the $[\mathrm{M}+\mathrm{D}]^{+}$ions of the 3-methylsubstituted ether than for the related ions of the unsubstituted ether if $\mathrm{CD}_{3} \mathrm{OD}$ or $\mathrm{CD}_{3} \mathrm{CN}$ is the $\mathrm{CI}$ reagent.

The influence on the product ion distribution is distinctly dependent on the position of the methyl group(s) with respect to the ether function. For example, the metastable $[M+D]^{+}$ions of the 3-methylphenyl $n$-propyl ether behave differently from the [M $+\mathrm{DJ}^{+}$ions derived from 4-methyl-substituted ethers in the sense that the latter ions eliminate $\mathrm{C}_{3} \mathrm{H}_{5} \mathrm{D}$ and $\mathrm{C}_{3} \mathrm{H}_{6}$ in a ratio that is similar to that obtained for the unsubstituted ether (see Tables 1 and 2). For the 2,6-dimethylphenyl $n$-propyl ether, deuteron transfer leads to metastable $[\mathrm{M}+\mathrm{D}]^{+}$ions that expel predominantly $\mathrm{C}_{3} \mathrm{H}_{6}$ on the microsecond time scale (Table 3 ). The loss of $\mathrm{C}_{3} \mathrm{H}_{5} \mathrm{D}$ from these $[M+D]^{+}$ions becomes somewhat more significant as the $\mathrm{CI}$ reagent is changed from $\mathrm{D}_{2} \mathrm{O}$ to $\mathrm{CD}_{3} \mathrm{CN}$. Even though the $[\mathrm{M}+\mathrm{D}]^{+}$ions of the unlabeled 3,5-dimethylphenyl n-propyl ether also prefer to expel $\mathrm{C}_{3} \mathrm{H}_{6}$, an increase in the importance of the loss of $\mathrm{C}_{3} \mathrm{H}_{5} \mathrm{D}$ is not observed upon substitution of $\mathrm{D}_{2} \mathrm{O}$ with $\mathrm{CD}_{3} \mathrm{CN}$ as the $\mathrm{CI}$ gas. In- 
Table 2. Relative importances (\%) of the losses of $\mathrm{C}_{3} \mathrm{H}_{3} \mathrm{D}_{3}, \mathrm{C}_{3} \mathrm{H}_{4} \mathrm{D}_{2}, \mathrm{C}_{3} \mathrm{H}_{5} \mathrm{D}$, and $\mathrm{C}_{3} \mathrm{H}_{6}$ from the metastable $[\mathrm{M}+\mathrm{D}]^{+}$ions of methyl-substituted phenyl $n$-propyl ethers and some deuterium-labeled analogs (see also text) ${ }^{\mathrm{a}}$

\begin{tabular}{|c|c|c|c|c|c|c|}
\hline \multirow{2}{*}{$\begin{array}{c}\text { Compound } \\
\mathrm{M} \\
\end{array}$} & \multirow{2}{*}{$\begin{array}{l}\text { Reactant } \\
\text { ion }\end{array}$} & \multirow{2}{*}{$\begin{array}{c}\mathrm{Cl} \\
\text { reagent }\end{array}$} & \multicolumn{4}{|c|}{ Importance of the loss of } \\
\hline & & & $\mathrm{C}_{3} \mathrm{H}_{3} \mathrm{D}_{3}$ & $\mathrm{C}_{3} \mathrm{H}_{4} \mathrm{D}_{2}$ & $\mathrm{C}_{3} \mathrm{H}_{5} \mathrm{D}$ & $\overline{\mathrm{C}_{3} \mathrm{H}_{6}}$ \\
\hline \multirow{3}{*}{$\overline{3-\mathrm{CH}_{3} \mathrm{C}_{6} \mathrm{H}_{4} \mathrm{OCH}_{2} \mathrm{CH}_{2} \mathrm{CH}_{3}{ }^{\mathrm{b}}}$} & {$[M+D]^{+}$} & $\mathrm{D}_{2} \mathrm{O}$ & & & 8 & $\overline{92}$ \\
\hline & & $\mathrm{CD}_{3} \mathrm{OD}$ & & & 13 & 87 \\
\hline & & $\mathrm{CD}_{3} \mathrm{CN}$ & & & 13 & 87 \\
\hline \multirow[t]{3}{*}{$3-\mathrm{CH}_{3} \mathrm{C}_{6} \mathrm{H}_{4} \mathrm{OCH}_{2} \mathrm{CD}_{2} \mathrm{CH}_{3}{ }^{\mathrm{C}}$} & {$[M+D]^{+}$} & $\mathrm{D}_{2} \mathrm{O}$ & 7 & 74 & 19 & \\
\hline & & $\mathrm{CD}_{3} \mathrm{OD}$ & 10 & 76 & 14 & \\
\hline & & $\mathrm{CD}_{3} \mathrm{CN}$ & 11 & 46 & 43 & \\
\hline \multirow[t]{3}{*}{ 4- $\mathrm{CH}_{3} \mathrm{C}_{6} \mathrm{H}_{4} \mathrm{OCH}_{2} \mathrm{CH}_{2} \mathrm{CH}_{3}{ }^{b}$} & {$[M+D]^{+}$} & $\mathrm{D}_{2} \mathrm{O}$ & & & 12 & 88 \\
\hline & & $\mathrm{CD}_{3} \mathrm{OD}$ & & & 23 & 77 \\
\hline & & $\mathrm{CD}_{3} \mathrm{CN}$ & & & 27 & 73 \\
\hline \multirow[t]{3}{*}{ 4- $\mathrm{CH}_{3} \mathrm{C}_{6} \mathrm{H}_{4} \mathrm{OCH}_{2} \mathrm{CD}_{2} \mathrm{CH}_{3}{ }^{\mathrm{C}}$} & {$[M+D]^{+}$} & $\mathrm{D}_{2} \mathrm{O}$ & 8 & 75 & 17 & \\
\hline & & $\mathrm{CD}_{3} \mathrm{OD}$ & 20 & 66 & 14 & \\
\hline & & $\mathrm{CD}_{3} \mathrm{CN}$ & 21 & 66 & 13 & \\
\hline
\end{tabular}

The relative importances given in the table are producible within $1 \%$.

${ }^{b}$ Propene loss from the $[\mathrm{M}+\mathrm{D}]^{+}$ions yields $\mathrm{CH}_{3} \mathrm{C}_{6} \mathrm{H}_{6} \mathrm{O}^{+}(\mathrm{m} / 2109)$ and $\mathrm{CH}_{3} \mathrm{C}_{6} \mathrm{H}_{5} \mathrm{DO}^{+}(\mathrm{m} / 2110)$ ions.

CPropene loss from the $[M+D]^{+}$ions leads to $\mathrm{CH}_{3} \mathrm{C}_{6} \mathrm{H}_{6} \mathrm{O}^{+}(\mathrm{m} / 2109) . \mathrm{CH}_{3} \mathrm{C}_{6} \mathrm{H}_{5} \mathrm{DO}^{+}(\mathrm{m} / 2110)$, and $\mathrm{CH}_{3} \mathrm{C}_{6} \mathrm{H}_{4} \mathrm{D}_{2} \mathrm{O}^{+}(\mathrm{m} / \mathrm{z} 111)$ ions.

Table 3. Relative importances (\%) of the losses of $\mathrm{C}_{3} \mathrm{H}_{3} \mathrm{D}_{3}, \mathrm{C}_{3} \mathrm{H}_{4} \mathrm{D}_{2}, \mathrm{C}_{3} \mathrm{H}_{5} \mathrm{D}$, and $\mathrm{C}_{3} \mathrm{H}_{6}$ from the metastable $[\mathrm{M}+\mathrm{D}]^{+}$ions of methyl-substituted phenyl $n$-propyl ethers and deuterium-labeled analogs (see also text) ${ }^{\mathrm{a}}$

\begin{tabular}{|c|c|c|c|c|c|c|}
\hline \multirow{2}{*}{$\begin{array}{c}\text { Compound } \\
\mathrm{M}\end{array}$} & \multirow{2}{*}{$\begin{array}{c}\text { Reactant } \\
\text { ion }\end{array}$} & \multirow{2}{*}{$\underset{\text { reagent }}{\mathrm{Cl}}$} & \multicolumn{4}{|c|}{ Importance of the loss of } \\
\hline & & & $\mathrm{C}_{3} \mathrm{H}_{3} \mathrm{D}_{3}$ & $\mathrm{C}_{3} \mathrm{H}_{4} \mathrm{D}_{2}$ & $\mathrm{C}_{3} \mathrm{H}_{5} \mathrm{D}$ & $\mathrm{C}_{3} \mathrm{H}_{6}$ \\
\hline \multirow[t]{3}{*}{$2,6-\left(\mathrm{CH}_{3}\right)_{2} \mathrm{C}_{6} \mathrm{H}_{3} \mathrm{OCH}_{2} \mathrm{CH}_{2} \mathrm{CH}_{3}{ }^{b}$} & {$[M+D]^{+}$} & $\mathrm{D}_{2} \mathrm{O}$ & & & 6 & 94 \\
\hline & & $C D_{3} O D$ & & & 8 & 92 \\
\hline & & $\mathrm{CD}_{3} \mathrm{CN}$ & & & 11 & 89 \\
\hline \multirow[t]{3}{*}{ 2.6- $\left(\mathrm{CH}_{3}\right)_{2} \mathrm{C}_{6} \mathrm{H}_{3} \mathrm{OCH}_{2} \mathrm{CD}_{2} \mathrm{CH}_{3}{ }^{\mathrm{c}}$} & {$[M+D]^{+}$} & $\mathrm{D}_{2} \mathrm{O}$ & 2 & 82 & 16 & \\
\hline & & $\mathrm{CD}_{3} \mathrm{OD}$ & 4 & 81 & 15 & \\
\hline & & $\mathrm{CD}_{3} \mathrm{CN}$ & 5 & 81 & 14 & \\
\hline \multirow{3}{*}{ 3,5- $\left(\mathrm{CH}_{3}\right)_{2} \mathrm{C}_{6} \mathrm{H}_{3} \mathrm{OCH}_{2} \mathrm{CH}_{2} \mathrm{CH}_{3}{ }^{\mathrm{b}}$} & {$[M+D]^{+}$} & $\mathrm{D}_{2} \mathrm{O}$ & & & 9 & 91 \\
\hline & & $\mathrm{CD}_{3} \mathrm{OD}$ & & & 7 & 93 \\
\hline & & $\mathrm{CD}_{3} \mathrm{CN}$ & & & 6 & 94 \\
\hline \multirow[t]{3}{*}{ 3,5- $\left(\mathrm{CH}_{3}\right)_{2} \mathrm{C}_{6} \mathrm{H}_{3} \mathrm{OCH}_{2} \mathrm{CD}_{2} \mathrm{CH}_{3}{ }^{\mathrm{c}}$} & {$[M+D]^{+}$} & $\mathrm{D}_{2} \mathrm{O}$ & 8 & 77 & 15 & \\
\hline & & $\mathrm{CD}_{3} \mathrm{OD}$ & 8 & 78 & 14 & \\
\hline & & $\mathrm{CD}_{3} \mathrm{CN}$ & 3 & 87 & 10 & \\
\hline \multirow[t]{3}{*}{ 2,4,6-( $\left(\mathrm{CH}_{3}\right)_{3} \mathrm{C}_{6} \mathrm{H}_{2} \mathrm{OCH}_{2} \mathrm{CH}_{2} \mathrm{CH}_{3}{ }^{d}$} & {$[M+D]^{+}$} & $\mathrm{D}_{2} \mathrm{O}$ & & & 4 & 96 \\
\hline & & $\mathrm{CD}_{3} \mathrm{OD}$ & & & 4 & 96 \\
\hline & & $\mathrm{CD}_{3} \mathrm{CN}$ & & & 4 & 96 \\
\hline \multirow[t]{3}{*}{ 2,4,6- $\left(\mathrm{CH}_{3}\right)_{3} \mathrm{C}_{6} \mathrm{H}_{2} \mathrm{OCH}_{2} \mathrm{CD}_{2} \mathrm{CH}_{3}{ }^{*}$} & {$[M+D]^{+}$} & $\mathrm{D}_{2} \mathrm{O}$ & 3 & 72 & 25 & \\
\hline & & $\mathrm{CD}_{3} \mathrm{OD}$ & 3 & 70 & 27 & \\
\hline & & $\mathrm{CD}_{3} \mathrm{CN}$ & 3 & 68 & 29 & \\
\hline
\end{tabular}

The relative importances given in the table are reproducible within $1 \%$

Propene loss from the $[\mathrm{M}+\mathrm{D}]^{+}$ions leads to $\left(\mathrm{CH}_{3}\right)_{2} \mathrm{C}_{6} \mathrm{H}_{5} \mathrm{O}^{+}\left(\mathrm{m} / 2\right.$ 123) and $\left(\mathrm{CH}_{3}\right)_{2} \mathrm{C}_{6} \mathrm{H}_{4} \mathrm{DO}^{+}(\mathrm{m} / 2$ 124) ions.

C Propene loss from the $[M+D]^{+}$ions leads to $\left(\mathrm{CH}_{3}\right)_{2} \mathrm{C}_{6} \mathrm{H}_{5} \mathrm{O}^{+}(\mathrm{m} / 2123),\left(\mathrm{CH}_{3}\right)_{2} \mathrm{C}_{6} \mathrm{H}_{4} \mathrm{DO}^{+}(\mathrm{m} / 2124)$. and $\left(\mathrm{CH}_{3}\right)_{2} \mathrm{C}_{6} \mathrm{H}_{3} \mathrm{D}_{2} \mathrm{O}^{+}(\mathrm{m} / 2125)$ ions.

${ }^{d}$ Propene loss from the $[\mathrm{M}+\mathrm{D}]^{+}$ions leads to $\left(\mathrm{CH}_{3}\right)_{3} \mathrm{C}_{6} \mathrm{H}_{4} \mathrm{O}^{+}\left(\mathrm{m} / 2\right.$ 137) and $\left(\mathrm{CH}_{3}\right)_{3} \mathrm{C}_{6} \mathrm{H}_{3} \mathrm{DOO}^{+}(\mathrm{m} / 2$ 138) ions.

Propene loss from the $[\mathrm{M}+\mathrm{D}]^{+}$ions leads to $\left(\mathrm{CH}_{3}\right)_{3} \mathrm{C}_{6} \mathrm{H}_{4} \mathrm{O}^{+}\left(\mathrm{m} / 2\right.$ 137), $\left(\mathrm{CH}_{3}\right)_{3} \mathrm{C}_{6} \mathrm{H}_{3} \mathrm{DO}{ }^{+}(\mathrm{m} / z$ 138). and $\left(\mathrm{CH}_{3}\right)_{3} \mathrm{C}_{6} \mathrm{H}_{2} \mathrm{D}_{3} \mathrm{O}^{+}(\mathrm{m} / 2139)$ ions. 
stead, the $[\mathrm{M}+\mathrm{D}]^{+}$ions of the 3,5-dimethylphenyl $n$-propyl ether tend to eliminate slightly less $\mathrm{C}_{3} \mathrm{H}_{5} \mathrm{D}$ as the initial deuteron transfer that leads to their formation becomes less exothermic. A noteworthy behavior is observed for the metastable $[\mathrm{M}+\mathrm{D}]^{+}$ions of the unlabeled 2,4,6-trimethylphenyl ether, which expel $\mathrm{C}_{3} \mathrm{H}_{5} \mathrm{D}$ and $\mathrm{C}_{3} \mathrm{H}_{6}$ in a ratio of $4: 96$ irrespective of whether $\mathrm{D}_{2} \mathrm{O}, \mathrm{CD}_{3} \mathrm{OD}$, or $\mathrm{CD}_{3} \mathrm{CN}$ is the $\mathrm{CI}$ reagent.

The trend observed in the relative importance of $\mathrm{C}_{3} \mathrm{H}_{3} \mathrm{D}_{3}$ loss from the metastable $[\mathrm{M}+\mathrm{D}]^{+}$ions of the methyl-substituted ethers labeled at the $\beta$ position of the propyl group is similar to the trend in the importance of the loss of $\mathrm{C}_{3} \mathrm{H}_{5} \mathrm{D}$ from the $[\mathrm{M}+\mathrm{D}]^{+}$ ions of the unlabeled ethers (see Tables 2 and 3 ). However, the effect of the presence of one or more methyl groups at the aromatic ring on the loss of propene is manifested more clearly in some of the results for the metastable $[M+D]^{+}$ions of the labeled methyl-substituted ethers than of the corresponding unlabeled species. For example, the metastable $[\mathrm{M}+$ D] ${ }^{+}$ions of $3-\mathrm{CH}_{3} \mathrm{C}_{6} \mathrm{H}_{4} \mathrm{OCH}_{2} \mathrm{CD}_{2} \mathrm{CH}_{3}$ expel $\mathrm{C}_{3} \mathrm{H}_{3} \mathrm{D}_{3}$, $\mathrm{C}_{3} \mathrm{H}_{4} \mathrm{D}_{2}$, and $\mathrm{C}_{3} \mathrm{H}_{5} \mathrm{D}$ in relative importances of 11:46:43 if $\mathrm{CD}_{3} \mathrm{CN}$ is the $\mathrm{CI}$ reagent. This finding reveals a more pronounced tendency to expel a propene molecule with only one deuterium atom than observed for the $[\mathrm{M}+\mathrm{D}]^{+}$ions of the labeled 4-methyl substituted ether, which expel $\mathrm{C}_{3} \mathrm{H}_{3} \mathrm{D}_{3}, \mathrm{C}_{3} \mathrm{H}_{4} \mathrm{D}_{2}$, and $\mathrm{C}_{3} \mathrm{H}_{5} \mathrm{D}$ in a ratio of 21:66:13 (Table 2). Furthermore, the introduction of two deuterium atoms at the $\beta$-position of the $n$-propyl group of the 2,4,6-trimethyl substituted ether reveals that that metastable $[\mathrm{M}+\mathrm{D}]^{+}$ions of this species eliminate $\mathrm{C}_{3} \mathrm{H}_{3} \mathrm{D}_{3}, \mathrm{C}_{3} \mathrm{H}_{4} \mathrm{D}_{2}$, and $\mathrm{C}_{3} \mathrm{H}_{5} \mathrm{D}$ in a ratio of 3:72:25 if $\mathrm{D}_{2} \mathrm{O}$ is the $\mathrm{CI}$ reagent. A similar ratio is obtained with the other two $\mathrm{CI}$ reagents, which indicates that the relative importance of $\mathrm{C}_{3} \mathrm{H}_{5} \mathrm{D}$ loss is almost independent of the nature of the $\mathrm{CI}$ reagent. Significantly, the loss of $\mathrm{C}_{3} \mathrm{H}_{5} \mathrm{D}$ from the metastable $[\mathrm{M}+\mathrm{D}]^{+}$ions of the labeled 2,4,6-trimethyl-substituted ether is more pronounced than for the $[\mathrm{M}+$ $\mathrm{Dl}^{+}$ions of most of the other deuterium-labeled methyl-substituted ethers (Table 3).

\section{Discussion}

The main features of the present results are (1) that the deuteron transferred to phenyl $n$-propyl ether or one of the methyl-substituted ethers can be exchanged with the hydrogen atoms of the alkyl chain prior to the explusion of propene on the microsecond time scale and (2) that propene loss proceeds without any significant interchange between the hydrogen atoms of the aromatic ring and the alkyl group. These findings are in agreement with results reported previously for phenyl $n$-propyl ether even though the present results have been obtained with water, methanol, or acetonitrile as the $\mathrm{CI}$ reagent instead of molecular hydrogen, methane, or 2-methylpropane as used in the earlier work [31,32]. One of the previous papers [32] suggested that propene loss occurs only from species protonated at the oxygen atom. Upon the assumption that this suggestion is valid, it could be thought that the interchange between the added deuteron and the seven hydrogen atoms of the $n$-propyl group is complete prior to propene loss from the metastable $[\mathrm{M}+$ $\mathrm{DJ}^{+}$ions of phenyl $n$-propyl ether. This suggestion leads then to the expectation that the ratio between the losses of $\mathrm{C}_{3} \mathrm{H}_{5} \mathrm{D}$ and $\mathrm{C}_{3} \mathrm{H}_{6}$ should be 75:25 if isotope effects are neglected. If it is assumed that the added deuteron interchanges with only six hydrogen atoms of the propyl entity, the predicted ratio between the losses of $\mathrm{C}_{3} \mathrm{H}_{5} \mathrm{D}$ and $\mathrm{C}_{3} \mathrm{H}_{6}$ becomes 71:29. Neither of these ratios is consistent with the experimentally obtained results for the unsubstituted ether (Table 1), which reveal that the added deuteron is retained in the product ions of propene loss to a much larger extent than anticipated from complete interchange between the deuteron and six or seven of the hydrogen atoms of the propyl entity. Clearly, such a simple analysis of propene loss is unable to account for the results for the metastable $[M+D]^{+}$ions of the various ethers included in the present study. In conclusion, a more detailed analysis of the initial deuteron transfer to the ethers as well as the ensuing propene loss is necessary to obtain some insight into the mechanism of the overall process.

For the present aryl $n$-propyl ethers, insight into the proton affinities of the different sites is not available and it is not possible a priori to infer the extent to which protonation occurs at the oxygen atom and the aromatic ring. For the simplest aromatic ether, $\mathrm{C}_{6} \mathrm{H}_{5} \mathrm{OCH}_{3}$, ab initio calculations suggest that the proton affinities of the oxygen atom and the 4 position of the ring are close to each other for the most stable conformer of this ether; that is, the conformer with the methoxy group in the plane of the aromatic ring [42]. For the 2 position, the proton affinity was calculated to be $8-12 \mathrm{~kJ} \mathrm{~mol}^{-1}$ lower than the value predicted for the 4 position, whereas the value for the 3 position was suggested to be about $60 \mathrm{~kJ} \mathrm{~mol}^{-1}$ lower than that of the 4 position. With respect to the aryl $n$-propyl ethers, it may be expected that the replacement of a methyl by an $n$-propyl group leads to an increase in the proton affinity of the oxygen atom $[19,20,37]$. Similarly, the introduction of one or more methyl groups at the phenyl ring is likely to increase the proton affinity of the aromatic ring in the ethers and, in addition, to introduce a steric hindrance to proton transfer to the site(s) that carry the methyl group(s). These considerations imply that the regioselectivity in proton transfer to the present.ethers may differ from that anticipated for the simplest species (methyl phenyl ether) and may be dependent on the number and positions of the methyl groups on the ring. Notwithstanding that the regioselectivity of the proton transfer to the ethers may be influenced by the presence of energy barriers, a relatively simple statistical model can be introduced for the analysis of the present results if it is assumed that propene loss is induced not only by deuteron 
transfer to the oxygen atom, but also to the aromatic ring as will be shown in subsequent text.

\section{Propene Loss from the $[M+D]^{+}$Ions of Phenyl $n$-Propyl Ether}

The first step in the statistical analysis of the results for the unsubstituted phenyl $n$-propyl ether is to assume that deuteron transfer to the oxygen atom is as probable as transfer to one of the carbon atoms at the 2, 4, and 6 position of the aromatic ring. Deuteron transfer to the 3 or 5 position of the ring may occur, of course, but is considered to be less favorable in view of the theoretical results for methyl phenyl ether [42]. In addition, deuteron transfer to the 3 or 5 position may lead to species that are less prone to expel propene in view of the fact that the positive charge in a formal sense is delocalized only over the 2,4 , and 6 positions of the ring. The distinction between species deuteronated at the 3 or 5 position and the ions formed by deuteron transfer to the 2,4 , or 6 position requires obviously that hydride-deuteride shifts that lead to the loss of positional identity of the hydrogen-deuterium atoms of the ring do not occur prior to propene loss from the latter metastable $[M+D]^{+}$ions (vide infra). The combination of the assumptions leads to the prediction that $25 \%$ of the total population of the $[\mathrm{M}+\mathrm{D}]^{+}$ions has the deuterium atom at the oxygen atom, $25 \%$ at the 4 position of the ring, and $50 \%$ at the 2 or 6 position (see Scheme I).

For the oxygen-deuteronated species derived from the unlabeled phenyl $n$-propyl ether, propene loss may be formulated as involving the formation of ion-neutral complexes as indicated in Scheme II [32, 35, 36]. In this scheme, the initial step is a heterolytic cleavage of the bond between the oxygen atom and the $\alpha$-carbon atom of the $n$-propyl group accompanied by an irreversible 1,2-hydride shift in the evolving primary carbenium ion [34]. The generated ion-neutral complex may then react by proton transfer from the secon-

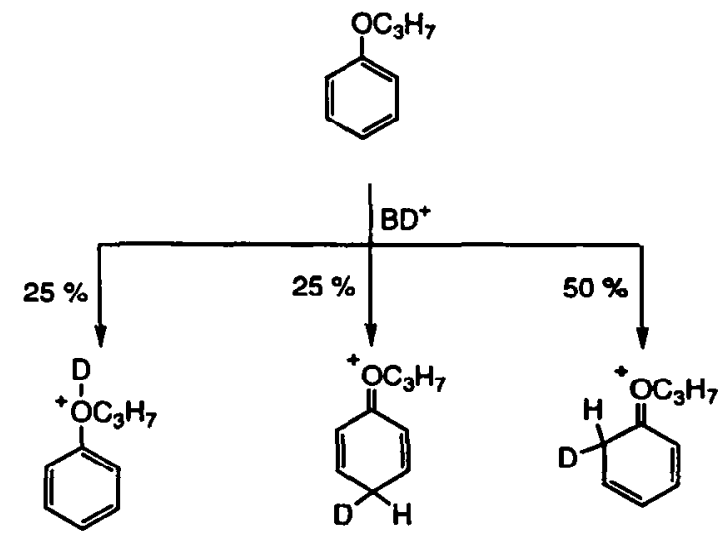

Scheme I. The assumed relative importances of deuteron transfer to the oxygen atom and one of the 2,4 , and 6 positions, respectively, of the aromatic ring in the phenyl $n$-propyl ether (see also text).

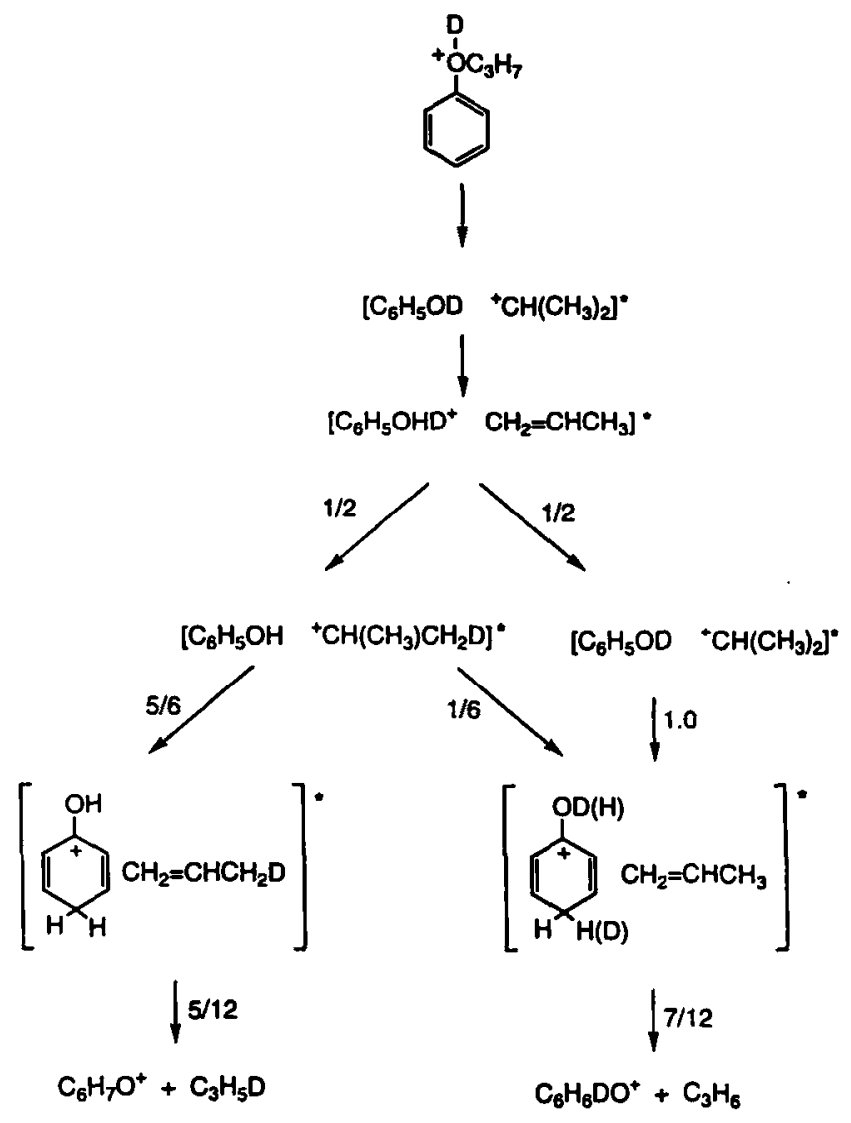

Scheme II. Proposed mechanism for the loss of propene initiated by deuteron transfer to the oxygen atom of the phenyl $n$-propyl ether. The numbers given for the reactions connecting the intermediate ion-neutral complexes represent statistical probabilities for the transfer of a proton and deuteron, respectively. The overall probabilities for the losses of $\mathrm{C}_{3} \mathrm{H}_{5} \mathrm{D}$ and $\mathrm{C}_{3} \mathrm{H}_{6}$ are given in the final steps of the reaction sequence (see also text).

dary propyl carbenium ion to the oxygen atom in the $\mathrm{C}_{6} \mathrm{H}_{5} \mathrm{OD}$ molecule present in the complex. The thus formed $\left[\mathrm{C}_{6} \mathrm{H}_{5} \mathrm{OHD}^{+} \mathrm{CH}_{2}=\mathrm{CH}-\mathrm{CH}_{3}\right]^{*}$ complex is considered to react further by proton or deuteron transfer with an equal probability. Subsequently, the $\left[\mathrm{C}_{6} \mathrm{H}_{5} \mathrm{OD}{ }^{+} \mathrm{CH}\left(\mathrm{CH}_{3}\right)_{2}\right]^{*}$ complex reacts by proton transfer and dissociation, whereas the $\left[\mathrm{C}_{6} \mathrm{H}_{5} \mathrm{OH}^{+} \mathrm{CH}\left(\mathrm{CH}_{3}\right) \mathrm{CH}_{2} \mathrm{D}\right]^{*}$ complex is assumed to undergo competing proton and deuteron transfer prior to dissociation. If isotope effects are neglected, the ratio between these two reactions within the latter complex becomes 5:1 as indicated in Scheme II. Overall, the statistical model given in this scheme leads to the prediction that initial deuteron transfer to the oxygen atom results in a ratio between the losses of $\mathrm{C}_{3} \mathrm{H}_{5} \mathrm{D}$ and $\mathrm{C}_{3} \mathrm{H}_{6}$ of $5: 7$, that is, $42 \% \mathrm{C}_{3} \mathrm{H}_{5} \mathrm{D}$ and $58 \%$ $\mathrm{C}_{3} \mathrm{H}_{6}$.

Loss of propene from the ions generated by deuteron transfer to the 2 or 4 position of the ring in the unsubstituted ether is shown in Scheme III. Based upon the assumption that these $[\mathrm{M}+\mathrm{D}]^{+}$ions of the unlabeled phenyl $n$-propyl ether expel only $\mathrm{C}_{3} \mathrm{H}_{6}$, the 


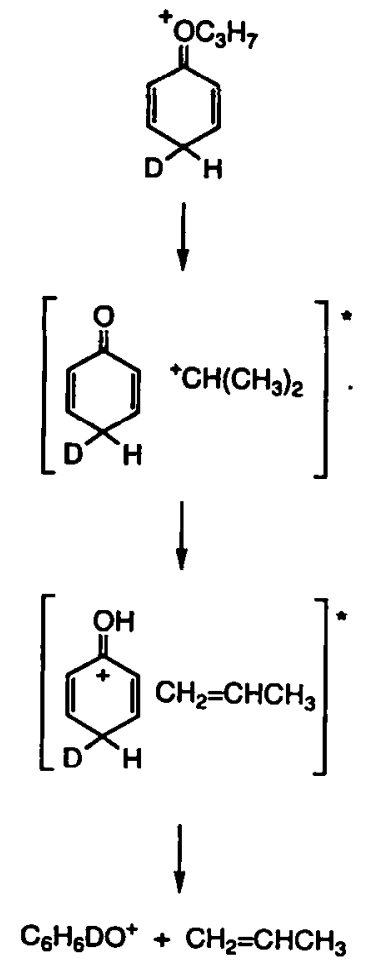

Scheme III. Proposed mechanism for the loss of propene initiated by deuteron transfer to the aromatic ring of the phenyl $n$-propyl ether (see also text). Only propene loss from the species formed by deuteron transfer to the 4 position is shown for reasons of simplicity.

overall ratio between the losses of $\mathrm{C}_{3} \mathrm{H}_{5} \mathrm{D}$ and $\mathrm{C}_{3} \mathrm{H}_{6}$ from the oxygen- and the ring-deuteronated species can now be predicted. For the oxygen-deuteronated species the relative importance of the loss of $\mathrm{C}_{3} \mathrm{H}_{5} \mathrm{D}$ becomes $0.25 \times 42 \%=10.5 \%$ whereas the relative contribution of the loss of $\mathrm{C}_{3} \mathrm{H}_{6}$ from these $[\mathrm{M}+\mathrm{D}]^{+}$ ions is expected to be $0.25 \times 58=14.5 \%$. In combination with the exclusive occurrence of the loss of $\mathrm{C}_{3} \mathrm{H}_{6}$ from the ring-deuteronated species, the final predicted ratio of the losses of $\mathrm{C}_{3} \mathrm{H}_{5} \mathrm{D}$ and $\mathrm{C}_{3} \mathrm{H}_{6}$ from the $\left[\mathrm{M}+\mathrm{D}^{+}\right.$ions of the phenyl $n$-propyl ether becomes 10.5:89.5 as indicated in Table 4.
A similar analysis allows an estimation of the predicted losses of $\mathrm{C}_{3} \mathrm{H}_{3} \mathrm{D}_{3}, \mathrm{C}_{3} \mathrm{H}_{4} \mathrm{D}_{2}$, and $\mathrm{C}_{3} \mathrm{H}_{5} \mathrm{D}$ from the $[\mathrm{M}+\mathrm{D}]^{+}$ions of the phenyl $n$-propyl ether labeled with two deuterium atoms at the $\beta$ position of the alkyl group. An essential feature of this analysis (see Appendix) is the assumed formation of a $\left.\left[\mathrm{C}_{6} \mathrm{H}_{5} \mathrm{OH}{ }^{+} \mathrm{CD}\left(\mathrm{CH}_{2} \mathrm{D}\right) \mathrm{CH}_{3}\right)\right]^{*}$ complex by initial deuteron transfer to the oxygen atom followed by oxygen-carbon bond cleavage and a single irreversible deuteride shift. These steps are succeeded by a limited number of proton-deuteron transfers between the components that involve the OD function, the deuterium atom, and the five hydrogen atoms of the methyl groups in the secondary carbenium ion. The final predicted relative importance of the competing losses of $\mathrm{C}_{3} \mathrm{H}_{3} \mathrm{D}_{3}, \mathrm{C}_{3} \mathrm{H}_{4} \mathrm{D}_{2}$, and $\mathrm{C}_{3} \mathrm{H}_{5} \mathrm{D}$ from the $[\mathrm{M}+\mathrm{D}]^{+}$ions of the labeled phenyl $n$-propyl ether becomes, with this approach, 7:77:16.

An important aspect of the model and the supporting schemes is the question of the site of proton transfer to the phenol molecule in the complexes. An inherent assumption in the model is that the interchange between hydrogen-deuterium atoms of the propyl group and the added deuteron occurs after initial transfer to the oxygen atom of the ether and involves proton transfer to the hydroxy group of the phenol molecules shown in Scheme II for the unlabeled phenyl $n$-propyl ether. The occurrence of proton-deuteron transfer from the generated $\mathrm{C}_{6} \mathrm{H}_{5} \mathrm{OHD}^{+}$ion to the propene molecule in the complex is in line with reported findings, which indicate that the proton affinity of the hydroxy group in phenol is close to the value for propene $[43,44]$. By contrast, the proton affinity of the 4 position of the ring in phenol is indicated to be about $60 \mathrm{~kJ} \mathrm{~mol}^{-1}$ higher than the proton affinity of the hydroxy group. Such a difference may indicate that deuteron-proton transfer to the ring of the phenol molecule present in the ion-neutral complexes is irreversible and leads to facile dissociation (see Scheme II) [45]. Furthermore, the proton affinity of the aromatic ring of phenol being larger than of the hydroxy function is in line with the suggestion that initial deuteron

Table 4. Estimated relative percentages of aromatic ring and oxygen atom deuteronation and the consequent importances (\%) of the losses of $\mathrm{C}_{3} \mathrm{H}_{3} \mathrm{D}_{3}, \mathrm{C}_{3} \mathrm{H}_{4} \mathrm{D}_{2}, \mathrm{C}_{3} \mathrm{H}_{5} \mathrm{D}$, and $\mathrm{C}_{3} \mathrm{H}_{6}$ from the metastable $[\mathrm{M}+\mathrm{D}]^{+}$ions of phenyl $n$-propyl ether and deuterium-labeled analogs (see text and Appendix)

\begin{tabular}{|c|c|c|c|c|c|c|c|}
\hline \multirow{2}{*}{$\begin{array}{l}\text { Compound } \\
\qquad M\end{array}$} & \multirow{2}{*}{$\begin{array}{l}\text { Reactant } \\
\text { ion }\end{array}$} & \multirow{2}{*}{ reagent } & \multirow{2}{*}{$\begin{array}{c}\text { Importance of } D^{+} \\
\text {transfer to ring:oxygen atom }\end{array}$} & \multicolumn{4}{|c|}{ Importance of the loss of } \\
\hline & & & & $\mathrm{C}_{3} \mathrm{H}_{3} \mathrm{D}_{3}$ & $\mathrm{C}_{3} \mathrm{H}_{4} \mathrm{D}_{2}$ & $\mathrm{C}_{3} \mathrm{H}_{5} \mathrm{D}$ & $\mathrm{C}_{3} \mathrm{H}_{6}$ \\
\hline \multirow[t]{3}{*}{$\overline{\mathrm{C}_{6} \mathrm{H}_{5} \mathrm{OCH}_{2} \mathrm{CH}_{2} \mathrm{CH}_{3}}$} & {$[M+D]^{+}$} & $\mathrm{D}_{2} \mathrm{O}$ & $75: 25^{8}$ & . & & 10.5 & 89.5 \\
\hline & & $\mathrm{CD}_{3} \mathrm{OD}$ & $67: 33^{b}$ & & & 18 & 82 \\
\hline & & $\mathrm{CD}_{3} \mathrm{CN}$ & $35: 65^{b}$ & & & 27 & 73 \\
\hline \multirow[t]{3}{*}{$\mathrm{C}_{6} \mathrm{H}_{5} \mathrm{OCH}_{2} \mathrm{CD}_{2} \mathrm{CH}_{3}$} & {$[M+D]^{+}$} & $\mathrm{D}_{2} \mathrm{O}$ & $75: 25^{\circ}$ & 7 & 77 & 16 & \\
\hline & & $\mathrm{CD}_{3} \mathrm{OD}$ & $67: 33^{b}$ & 19 & 70 & 11 & \\
\hline & & $\mathrm{CD}_{3} \mathrm{CN}$ & $35: 65^{b}$ & 21 & 67 & 12 & \\
\hline
\end{tabular}

\footnotetext{
Assumed relative importance of deuteron transfer to the aromatic ring and the oxygen atom (see text and Scheme 1).

Estimated relative importances of deuteron transfer to the ring and the oxygen atom. The estimation of these values is based upon the assumption that the experimentally determined ratios between the losses of labeled and unlabeled propene molecules are a result of the occurrence of competing deuteron transfer to the ring and the oxygen atom of the phenyl $n$-propyl ether (see also text).
} 
transfer to the ring of the phenyl $n$-propyl ether leads to complete retention of the added deuterium atom in the product ions formed by propene loss as visualized in Scheme III.

Both of the predicted ratios for the loss of propene from the metastable $[\mathrm{M}+\mathrm{D}]^{+}$ions of the (un)labeled phenyl $n$-propyl ether are in striking agreement with the experimental results obtained with $\mathrm{D}_{2} \mathrm{O}$ as the $\mathrm{CI}$ reagent as can be seen by comparison of the data in Tables 1 and 4 . This agreement between the experimental and predicted results for $\mathrm{D}_{2} \mathrm{O}$ as the $\mathrm{CI}$ reagent supports the assumption that deuteron transfer to the ring as well as to the oxygen atom leads to $[\mathrm{M}+\mathrm{D}]^{+}$ions that expel propene on the microsecond time scale. The former deuteron transfer leads, of course, to oxonium ions, whereas deuteron transfer to the oxygen atom leads to an isomeric species as indicated in Scheme I. In the model, it is assumed that the isomeric metastable $[\mathrm{M}+\mathrm{D}]^{+}$ions expel propene with the same overall rate on the microsecond time scale, which indicates that these reactions may be associated with similar critical energies. Unfortunately, no experimental information is available with respect to the energetics of propene loss from the different $[M+D]^{+}$ions of phenyl $n$-propyl ether. However, the endothermicity of propene loss from the simple oxonium ion, $\mathrm{CH}_{2}={ }^{+} \mathrm{OCH}_{2} \mathrm{CH}_{2} \mathrm{CH}_{3}$, is indicated to be $145 \mathrm{~kJ} \mathrm{~mol}^{-1}$ [46], whereas the loss of propene from protonated methyl $n$-propyl ether, $\mathrm{CH}_{3}^{+} \mathrm{O}(\mathrm{H}) \mathrm{CH}_{2} \mathrm{CH}_{2} \mathrm{CH}_{3}$, is estimated to be only slightly lower; that is, $130 \mathrm{~kJ} \mathrm{~mol}^{-1}$ [46].

Deuteron transfer from the $\mathrm{D}_{3} \mathrm{O}^{+}$ion to the phenyl $n$-propyl ether is, of course, more exothermic than from the $\mathrm{CD}_{3} \mathrm{OD}_{2}^{+}$and $\mathrm{CD}_{3} \mathrm{CND}^{+}$ions [37]. For the former ion, the agreement between the experimental results obtained with $\mathrm{D}_{2} \mathrm{O}$ as the $\mathrm{CI}$ reagent and the ratios predicted from the model then suggests that in a relatively exothermic reaction with the ether, the difference in proton affinities of the distinct sites in the ether and in the heights of the possible energy barriers toward deuteron transfer may not be sufficiently large to induce a regioselectivity in the overall process. In other words, deuteron transfer from the $\mathrm{D}_{3} \mathrm{O}^{+}$ion is likely to be a nonselective process. In the less exothermic reactions of the $\mathrm{CD}_{3} \mathrm{OD}_{2}^{+}$and $\mathrm{CD}_{3} \mathrm{CND}^{+}$ions, respectively, the difference in proton affinities and the barrier heights may be relatively pronounced and may induce a preference for deuteron transfer to a given site in the ether. The deviation between the predicted ratio and the experimental results for metastable $[\mathrm{M}+$ $\mathrm{D}^{+}$ions formed in the reactions of the latter two ionic species with the ether may thus be suggested to be a result of a change in the relative importance of deuteron transfer to the ring and oxygen atom. If the experimentally obtained results are assumed to reflect such a change, it can be estimated that the relative importance of deuteron transfer to the aromatic ring and the oxygen atom is $67 \%$ and $33 \%$, respectively, in the reaction of the $\mathrm{CD}_{3} \mathrm{OD}_{2}^{+}$ion with the phenyl $n$-propyl ether. Similarly, the experimental results obtained with $\mathrm{CD}_{3} \mathrm{CN}$ as the $\mathrm{CI}$ reagent lead to the prediction that the relative importance of ring and oxygen atom deuteronation is $35 \%$ and $65 \%$, respectively (see also Table 4). This analysis of experimental findings for $\mathrm{CD}_{3} \mathrm{OD}$ or $\mathrm{CD}_{3} \mathrm{CN}$ as the $\mathrm{CI}$ reagent suggests that deuteron transfer to the oxygen atom is either thermodynamically favored and/or associated with a lower energy barrier than for ring deuteronation.

It should be mentioned that a less exothermic reaction can result in metastable $[\mathrm{M}+\mathrm{D}]^{+}$ions that may have a lower internal energy than formed in a strongly exothermic deuteron transfer. The intermediate ionneutral complexes formed in the former situation may have a relatively long lifetime, which allows for the occurrence of reversibility in the deuteron-proton transfer prior to dissociation (see also Scheme II) [35, 36]. As a result, the tendency to incorporate the added deuterium atom in the propene molecule can become more pronounced if the initial step leading to the $[\mathrm{M}+\mathrm{D}]^{+}$ions is less exothermic. This may contribute to the observed results for $\mathrm{CD}_{3} \mathrm{OD}$ or $\mathrm{CD}_{3} \mathrm{CN}$ as the $\mathrm{CI}$ reagent in addition to the suggested variation in the competition between deuteron transfer to the ring and oxygen atom. However, a combination of both of these aspects of the overall process introduces too many unknowns for a simple analysis of the experimental findings, which are restricted to the measurements of relative abundances of the product ions of propene loss from the metastable $[M+D]^{+}$ions of the phenyl $n$-propyl ether and some labeled analogs.

A similar complication applies to other models that could be introduced to provide a mechanistic scheme that accounts for the incorporation of the added deuteron into the expelled propene molecule. For example, it could be thought that propene loss ensues only after initial deuteron transfer to the oxygen atom of the ether function [32, 33]. Subsequently, the bond between the oxygen atom and the $\alpha$-carbon atom of the $n$-propyl group may be cleaved concomitantly with a 1,2-hydride shift in the evolving carbenium ion. The thus formed ion-neutral complex of a phenol molecule and a secondary propyl carbenium ion could then react further by competing proton transfer to the oxygen atom and the aromatic ring of the neutral species. Interchange between the added deuteron and the hydrogen atoms of the carbenium ion is still expected to involve only the oxygen-protonated phenol molecule, whereas proton transfer to the ring could be irreversible and lead to facile dissociation (vide supra). This implies that the degree of interchange between the added deuteron and the hydrogen atoms of the $n$-propyl group is a result only of the competing reactions of the ion-neutral complexes formed by initial deuteron transfer to the oxygen atom. In terms of a more quantitative analysis, this introduces a number of uncertain variables with respect to the relative rates of the different pathways open to the initial ion-neutral complexes as well as the number of proton- 
deuteron transfers that occur in the complexes prior to ring protonation-deuteronation of the phenol molecule and the ensuring dissociation. In conclusion, such an alternative model appears not only to be complex, but also to be inconsistent with the expected occurrence of deuteron transfer to the ring as well as the oxygen atom of aromatic ethers in general and with the anticipated behavior of the oxonium-type ions formed by ring deuteronation. In conclusion, it should be noted that the model introduced in this study allows consistency to be obtained between the experimental and predicted results in a relatively simple and straightforward manner for the $[\mathrm{M}+\mathrm{D}]^{+}$ions of phenyl $n$-propyl ether formed with $\mathrm{D}_{2} \mathrm{O}$ as $\mathrm{CI}$ reagent as well as for the related ions derived from the methyl-substituted species (vide infra).

\section{Propene Loss from the $[M+D]^{+}$lons of Methyl-Substituted Phenyl n-Propyl Ethers}

The results for the methyl-substituted ethers can be discussed, in principle, on the basis of the same statistical model as applied for the unsubstituted phenyl $n$-propyl ether. The assumed relative importances of the $[\mathrm{M}+\mathrm{D}]^{+}$ions formed by deuteron transfer to the ring and oxygen atom, respectively, in the propene loss are given in Table 5 for the various methyl-substituted ethers. These ratios are based upon the tacit assumptions that the introduction of a methyl group prevents deuteron attachment to the site to which the methyl group is bonded and that deuteron transfer to a 3 or 5 position does not lead to metastable ions that eliminate propene (vide supra).

For the 4-methyl-substituted ether, this leads to the prediction that the relative importance of deuteron transfer to the ring and oxygen is 67:33. For the [M+ $\mathrm{D}^{+}$ions of the unlabeled 4-methyl-substituted ether, the estimated ratio between the losses of the $\mathrm{C}_{3} \mathrm{H}_{5} \mathrm{D}$ and $\mathrm{C}_{3} \mathrm{H}_{6}$ becomes 14:86. This value is in line with the experimental ratio of 12:88 obtained with $\mathrm{D}_{2} \mathrm{O}$ as the $\mathrm{CI}$ reagent, whereas the results for $\mathrm{CD}_{3} \mathrm{OD}$ or $\mathrm{CD}_{3} \mathrm{CN}$ as $\mathrm{CI}$ reagent reveal a more pronounced tendency to expel $\mathrm{C}_{3} \mathrm{H}_{5} \mathrm{D}$ (see Table 2). In analogy with the discussion of the findings for the unsubstituted ether this may be interpreted to be largely a result of an increased importance of deuteron transfer to the oxygen atom as the exothermicity of the initial acid-base reaction is decreased. For the 3-methyl-substituted species, the statistical model predicts that the $[\mathrm{M}+\mathrm{D}]^{+}$ions of this ether should expel $\mathrm{C}_{3} \mathrm{H}_{5} \mathrm{D}$ and $\mathrm{C}_{3} \mathrm{H}_{6}$ in the same ratio as the phenyl $n$-propyl ether. This holds essentially for the results obtained with $\mathrm{D}_{2} \mathrm{O}$ as the $\mathrm{CI}$ reagent, whereas the use of $\mathrm{CD}_{3} \mathrm{OD}$ or $\mathrm{CD}_{3} \mathrm{CN}$ leads only to slightly more loss of $\mathrm{C}_{3} \mathrm{H}_{5} \mathrm{D}$ as predicted from propene loss initiated by a nonselective deuteron transfer to the oxygen atom and one of the 2, 4, and 6 positions of the ring. This behavior is in contrast to the findings for the unsubstituted as well as the 4-methylsubstituted ether, which suggest a preference for transfer to the oxygen atom in the experiments with the latter two $\mathrm{CI}$ reagents. In terms of the proton affinity of the different sites within the monomethyl-substituted ethers, the presence of a methyl group at the 3 position is likely to increase the proton affinity of the ring relatively more than a methyl group at the 4 position. This is in line with the reported proton affinities of, for example, dimethylbenzenes, which indicate that the proton affinity of 1,3-dimethylbenzene is $\approx 17 \mathrm{~kJ}$ $\mathrm{mol}^{-1}$ higher than the value of 1,4-dimethylbenzene [37]. Notwithstanding that the proton affinities of the various sites in the present ethers are unknown, the results indicate that the relative extent of deuteron transfer to the ring and the oxygen atom of the 3methyl-substituted ether is largely unaffected by the change in exothermicity of the initial deuteron transfer. This also is reflected in the results for the 3-methylsubstituted ether labeled with two deuterium atoms at the $\beta$ position (see Tables 2 and 5). However, in the experiments with $\mathrm{CD}_{3} \mathrm{CN}$ as the $\mathrm{CI}$ reagent, the metastable $[\mathrm{M}+\mathrm{D}]^{+}$ions of the labeled 3-methyl-substituted ether expel almost equal amounts of $\mathrm{C}_{3} \mathrm{H}_{4} \mathrm{D}_{2}$ and $\mathrm{C}_{3} \mathrm{H}_{5} \mathrm{D}$, whereas the relative importance of the

Table 5. Estimated relative importances (\%) of the losses of $\mathrm{C}_{3} \mathrm{H}_{3} \mathrm{D}_{3}, \mathrm{C}_{3} \mathrm{H}_{4} \mathrm{D}_{2}, \mathrm{C}_{3} \mathrm{H}_{5} \mathrm{D}$, and $\mathrm{C}_{3} \mathrm{H}_{6}$ from the metastable [M $\left.+\mathrm{D}\right]^{+}$ ions of the methyl-substituted phenyl $n$-propyl ethers and deuterium-labeled analogs formed by a reaction of $\mathrm{M}$ with $\mathrm{D}_{3} \mathrm{O}^{+}$ (see also text)

\begin{tabular}{|c|c|c|c|c|c|c|}
\hline \multirow{2}{*}{$\begin{array}{c}\text { Compound } \\
\mathrm{M}\end{array}$} & \multirow{2}{*}{$\begin{array}{l}\text { Reactant } \\
\text { ion }\end{array}$} & \multirow{2}{*}{$\begin{array}{l}\text { Assumed importance of } \mathrm{D}^{+} \\
\text {transfer to ring:oxygen }\end{array}$} & \multicolumn{4}{|c|}{ Estimated importance of the loss of } \\
\hline & & & $\mathrm{C}_{3} \mathrm{H}_{3} \mathrm{D}_{3}$ & $\mathrm{C}_{3} \mathrm{H}_{4} \mathrm{D}_{2}$ & $\mathrm{C}_{3} \mathrm{H}_{5} \mathrm{D}$ & $\mathrm{C}_{3} \mathrm{H}_{6}$ \\
\hline $\begin{array}{l}\text { 3- } \mathrm{CH}_{3} \mathrm{C}_{6} \mathrm{H}_{4} \mathrm{OCH}_{2} \mathrm{CH}_{2} \mathrm{CH}_{3} \\
3-\mathrm{CH}_{3} \mathrm{C}_{6} \mathrm{H}_{4} \mathrm{OCH}_{2} \mathrm{CD}_{2} \mathrm{CH}_{3}\end{array}$ & $\begin{array}{l}{[M+D]^{+}} \\
{[M+D]^{+}}\end{array}$ & $\begin{array}{l}75: 25 \\
75: 25\end{array}$ & 7 & 77 & $\begin{array}{l}10.5 \\
16\end{array}$ & 89.5 \\
\hline $4-\mathrm{CH}_{3} \mathrm{C}_{8} \mathrm{H}_{4} \mathrm{OCH}_{2} \mathrm{CH}_{2} \mathrm{CH}_{3}$ & {$[M+D]^{+}$} & $67: 33$ & & & 14 & 86 \\
\hline 4- $\mathrm{CH}_{3} \mathrm{C}_{6} \mathrm{H}_{4} \mathrm{OCH}_{2} \mathrm{CD}_{2} \mathrm{CH}_{3}$ & {$[M+D]^{+}$} & $67: 33$ & 9 & 76 & 15 & \\
\hline 2,6-( $\left(\mathrm{CH}_{3}\right)_{2} \mathrm{C}_{6} \mathrm{H}_{3} \mathrm{OCH}_{2} \mathrm{CH}_{2} \mathrm{CH}_{3}$ & {$[M+D]^{+}$} & $50: 50$ & & & 21 & 79 \\
\hline 2,6-( $\left(\mathrm{CH}_{3}\right)_{2} \mathrm{C}_{6} \mathrm{H}_{3} \mathrm{OCH}_{2} \mathrm{CD}_{2} \mathrm{CH}_{3}$ & {$[\mathrm{M}+\mathrm{D}]^{+}$} & $50: 50$ & 14 & 72.5 & 13.5 & \\
\hline $3,5-\left(\mathrm{CH}_{3}\right)_{2} \mathrm{C}_{6} \mathrm{H}_{3} \mathrm{OCH}_{2} \mathrm{CH}_{2} \mathrm{CH}_{3}$ & {$[M+D]^{+}$} & $75: 25$ & & & 10.5 & 89.5 \\
\hline $3,5-\left(\mathrm{CH}_{3}\right)_{2} \mathrm{C}_{6} \mathrm{H}_{3} \mathrm{OCH}_{2} \mathrm{CD}_{2} \mathrm{CH}_{3}$ & {$[M+D]^{+}$} & $75: 25$ & 7 & 77 & 16 & \\
\hline $2,4,6-\left(\mathrm{CH}_{3}\right)_{3} \mathrm{C}_{6} \mathrm{H}_{2} \mathrm{OCH}_{2} \mathrm{CH}_{2} \mathrm{CH}_{3}$ & {$[M+D]^{+}$} & $0: 100$ & & & 42 & 58 \\
\hline $2,4,6-\left(\mathrm{CH}_{3}\right)_{3} \mathrm{C}_{6} \mathrm{H}_{2} \mathrm{OCH}_{2} \mathrm{CD}_{2} \mathrm{CH}_{3}$ & {$[M+D]^{+}$} & $0: 100$ & 28 & 62 & 10 & \\
\hline
\end{tabular}

\footnotetext{
Assumed relative importance of deuteron transfer to the aromatic ring and the oxygen atom of the methyl-substituted phenyl $n$-propyl ethers (see also text).
} 
loss of $\mathrm{C}_{3} \mathrm{H}_{3} \mathrm{D}_{3}$ is essentially the same for the three $\mathrm{CI}$ reagents (see Table 2). The marked loss of $\mathrm{C}_{3} \mathrm{H}_{5} \mathrm{D}$ from the $[\mathrm{M}+\mathrm{D}]^{+}$ions of this particular ether may be a result of a reaction pathway that involves a specific transfer of a deuterium atom from the $\beta$ position of the $n$-propyl group to the remaining part of the ion. Even though the precise reaction sequence is unknown, it is not unlikely that this competing reaction is initiated by deuteron transfer to the aromatic ring.

An increase in the relative importance of propene loss from the ring-deuteronated species can also account for the results obtained for the metastable [M+ $\mathrm{D}^{+}$ions of the 3,5-dimethylphenyl $n$-propyl ether. However, the presence of a methyl group at the 5 as well as the 3 position appears not to lead to a marked tendency for the loss of $\mathrm{C}_{3} \mathrm{H}_{5} \mathrm{D}$ from the $[\mathrm{M}+\mathrm{D}]^{+}$ ions formed with $\mathrm{CD}_{3} \mathrm{CN}$ as the $\mathrm{CI}$ reagent (see Table 3). For the 2,6-dimethyl- and 2,4,6-trimethylphenyl $n$ propyl ethers, the assumed relative importances of deuteron transfer to the ring and the oxygen atom lead to predicted ratios for the loss of labeled and unlabeled propene molecules that deviate significantly from the experimental findings (see Tables 3 and 5). For example, deuteron transfer to the 4 position of the ring and the oxygen atom of the 2,6-dimethyl-substituted ether is assumed in the model to be equally probable (see Table 5) and predicted to lead to a ratio of 21:79 between the losses of $\mathrm{C}_{3} \mathrm{H}_{5} \mathrm{D}$ and $\mathrm{C}_{3} \mathrm{H}_{6}$ from the $[\mathrm{M}+\mathrm{D}]^{+}$ions. This ratio is in disagreement with the experimental findings, which reveal that the ratio between the losses of $\mathrm{C}_{3} \mathrm{H}_{5} \mathrm{D}$ and $\mathrm{C}_{3} \mathrm{H}_{6}$ is 6:94 for $\mathrm{D}_{2} \mathrm{O}$ as $\mathrm{CI}$ reagent and $11: 89$ if $\mathrm{CD}_{3} \mathrm{CN}$ is the $\mathrm{CI}$ reagent. The experimental results may be understood, however, in terms of an increased relative importance of propene loss from ring-deuteronated species. This is indicated more clearly by the findings for the $[M+D]^{+}$ ions of the labeled 2,6-dimethylphenyl $n$-propyl ether, which show that these ions eliminate only minor amounts of $\mathrm{C}_{3} \mathrm{H}_{3} \mathrm{D}_{3}$ as compared to the losses of $\mathrm{C}_{3} \mathrm{H}_{4} \mathrm{D}_{2}$ and $\mathrm{C}_{3} \mathrm{H}_{5} \mathrm{D}$ regardless of the nature of the $\mathrm{CI}$ reagent (see Table 3). A scheme that is consistent with the results involves predominantly deuteron transfer to the ring followed by cleavage of the bond between the oxygen atom and the $\alpha$-carbon atom of the $n$-propyl group accompanied by a single irreversible deuteride shift (see Scheme IV). This may lead to a complex of a 2,6-dimethyl-2,5-cyclohexadienone molecule with a deuterium atom at the 4 position and a $\left(\mathrm{CDH}_{2}\right) \mathrm{CH}_{3} \mathrm{CD}^{+}$ion. Subsequently, proton or deuteron transfer from one of the methyl groups in the carbenium ion part of the complex may occur. If isotope effects are neglected, this leads to a predicted ratio 83:17 between the losses of $\mathrm{C}_{3} \mathrm{H}_{4} \mathrm{D}_{2}$ and $\mathrm{C}_{3} \mathrm{H}_{5} \mathrm{D}$, which is close to the experimental results for the three CI reagents (see Table 3 ).

Propene loss from some of the present $\mathrm{di}-$ and trimethylphenyl $n$-propyl ethers may, however, be a more complex process than suggested by the assumptions introduced in the analysis of the relative impor-<smiles>CC(=O)Oc1c(C)cccc1C</smiles><smiles>[Te-][I-]</smiles><smiles>[2H][C@H]1C=C(C)[C@H](OC(C)=O)C(C)=C1</smiles>
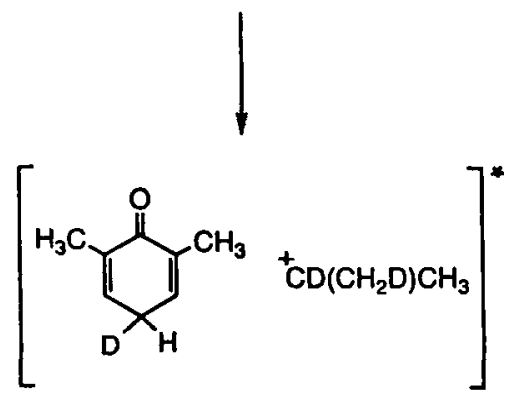

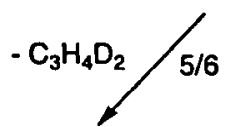

$\mathrm{C}_{8} \mathrm{H}_{10} \mathrm{DO}^{+}$

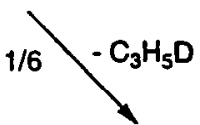

$\mathrm{C}_{8} \mathrm{H}_{9} \mathrm{D}_{2} \mathrm{O}^{+}$
Scheme IV. Possible mechanism for the loss of propene initiated by deuteron transfer to the aromatic ring of the 2,6-dimethylphenyl $n$-propyl ether labeled with two deuterium atoms at the $\beta$ position of the alkyl group (see also text).

tances of the losses of labeled and unlabeled propene molecules from the metastable $[\mathrm{M}+\mathrm{D}]^{+}$ions. This can be illustrated by the results for the ions formed by deuteron transfer to the 2,4,6-trimethylphenyl $n$-propyl ether. According to the assumptions on which the statistical models are based, deuteron transfer to a methyl-substituted position is an unlikely process and, in addition, propene loss is considered not to occur from ions formed by initial deuteron transfer to the 3 or 5 position (vide supra). For the 2,4,6-trimethyl-substituted ether, this implies that deuteron transfer to the ring does not lead to ions that expel propene or, stated otherwise, the findings for this ether (see Table 3) could be a result of the exclusive occurrence of propene loss from the ions formed by initial deuteron transfer to the oxygen atom. However, the experimental results for the $[\mathrm{M}+\mathrm{D}]^{+}$ions of the unlabeled 2,4,6-trimethylphenyl $n$-propyl ether indicate clearly that the added deuterium atom is retained predominantly in the product ions of propene loss. If only oxygen-deuteronated species were involved in the propene loss, it could be anticipated that the added deuterium atom is incorporated to a larger extent into the expelled 
propene molecules than observed. Moreover, similar results with respect to the relative importances of the losses of $\mathrm{C}_{3} \mathrm{H}_{4} \mathrm{D}_{2}$ and $\mathrm{C}_{3} \mathrm{H}_{5} \mathrm{D}$ could be expected from the 2,4,5-trimethyl-substituted and for the 2,6-dimethylphenyl $n$-propyl ether in contrast to the experimental findings. Significantly, the ratio between the losses of $\mathrm{C}_{3} \mathrm{H}_{4} \mathrm{D}_{2}$ and $\mathrm{C}_{3} \mathrm{H}_{5} \mathrm{D}$ from the $[\mathrm{M}+\mathrm{D}]^{+}$ions of the labeled 2,4,6-trimethyl-substituted ether (Table 3) are in line with the occurrence of complete loss of positional identity of the five hydrogen and two deuterium atoms of the propyl group prior to dissociation. This could be taken to mean that the overall process involves initial deuteron transfer to either the 3 or 5 position of the ring. The ions thus formed may then dissociate or undergo a 1,2-hydride-deuteride shift [2] that leads to ions with a hydrogen or deuterium atom and a methyl group at the 4 position as shown in Scheme V. The latter ions subsequently may form an ion-neutral complex composed of a trimethyl-substituted 2,5-cyclohexadienone molecule and $\mathrm{a} \mathrm{C}_{3} \mathrm{H}_{5} \mathrm{D}_{2}^{+}$ ion. If this complex is generated with a sufficient internal energy it may allow for randomization of the five hydrogen and two deuterium atoms of the carbenium ion prior to proton or deuteron transfer within the complex and the ensuing expulsion of propene. This suggests that the loss of propene from the [M + $\mathrm{D}^{+}$ions of the 2,4,6-trimethyl-substituted ether is associated with a larger critical energy than the loss of propene from the ions generated by deuteron transfer to the other ethers included in this study.

\section{Conclusions}

Chemical ionization of phenyl $n$-propyl ether and a series of methyl-substituted analogs with the reagents, $\mathrm{D}_{2} \mathrm{O}, \mathrm{CD}_{3} \mathrm{OD}$, or $\mathrm{CD}_{3} \mathrm{CN}$ (in order of increasing proton affinity) leads to $[M+D]^{+}$ions that dissociate only by the loss of propene. Partial exchange between the added deuteron and the hydrogen atoms of the $n$-propyl group occurs prior to propene loss, whereas interchange between the hydrogen atoms of the phenyl and $n$-propyl groups is of negligible importance. The experimentally observed relative importances of the losses of the labeled and unlabeled propene molecules from the metastable $[\mathrm{M}+\mathrm{D}]^{+}$ions and a series of deuterium-labeled analogs are discussed on the basis of a model that assumes the occurrence of competing deuteron transfer to the oxygen atom and the aromatic ring of the ether. Within this model, the transfer of a deuteron to the ether function is held responsible for the partial incorporation of the added deuteron in the expelled propene molecules, whereas deuteron transfer to the ring is suggested to yield species that eliminate propene molecules that contain only the hydrogen atoms of the original $n$-propyl group in the parent compound. Based upon this model, the results obtained for phenyl $n$-propyl ether with $\mathrm{D}_{2} \mathrm{O}$ as the $\mathrm{CI}$ reagent can be reproduced if it is assumed that deuteron transfer to the oxygen atom and one of the 2 ,<smiles>CC(=O)COc1cc(C)cc(C)c1OC(C)=O</smiles><smiles>CC(=O)COc1cc(C)cc(C)c1COC(C)=O</smiles>

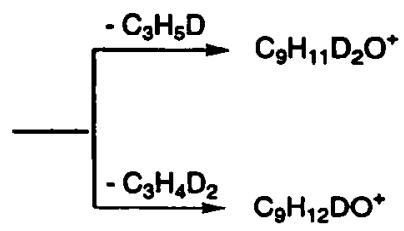

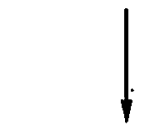

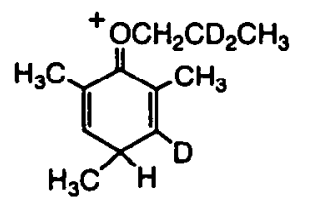<smiles>[3H]I</smiles><smiles>CC1=C[C@H](C)[C@H](O)C(C)=C1C</smiles>

Scheme V. Possible mechanism for propene loss initiated by deuteron transfer to the aromatic ring of the 2,4,6-trimethylphenyl $n$-propyl ether labeled with two deuterium atoms at the $\beta$ position of the alkyl group (see also text).

4 , and 6 positions of the ring is equally probable and isotope effects are neglected. For $\mathrm{CD}_{3} \mathrm{OD}$ or $\mathrm{CD}_{3} \mathrm{CN}$ as the $\mathrm{CI}$ reagent, the results are taken to mean that deuteron transfer to the oxygen atom is favored over transfer to one of the 2,4 , or 6 positions of the ring and/or that the oxygen-deuteronated species may expel propene with the added deuteron to a somewhat larger extent than if it were formed with $\mathrm{D}_{2} \mathrm{O}$ as the $\mathrm{CI}$ reagent.

The model also allows the findings for methyl-substituted ethers to be discussed in terms of competing deuteron transfer to the ring and the oxygen atom. The relative importance of the deuteron transfer to the different sites appears to depend upon the site and the number of methyl groups attached to the aromatic ring. In particular, for the 4-methylphenyl $n$-propyl ether, the results appear to reflect that propene loss is induced by deuteron transfer to the oxygen atom and 
the 2 or 6 position of the ring, whereas the results for the $[\mathrm{M}+\mathrm{D}]^{+}$ions of the 3-methyl-substituted species are more consistent with a preference for deuteron transfer to the ring irrespective of the nature of the $\mathrm{CI}$ reagent. A similar situation applies to the 3,5-dimethyl-substituted ether even though propene loss from the oxygen-atom-deuteronated species still plays a role. For the 2,6-dimethyl- and the 2,4,6-trimethylphenyl $n$-propyl ethers, however, the results seem to indicate that propene loss occurs predominantly from ring-deuteronated species.

\section{Acknowledgments}

The authors thank the Netherlands Organization for Scientific Research (SON/NWO) for financial support and T. A. MolenaarLangeveld for assistance during the synthesis of some of the deuterium-labeled ethers.

\section{Appendix}

The relative importances of the losses of $\mathrm{C}_{3} \mathrm{H}_{3} \mathrm{D}_{3}$, $\mathrm{C}_{3} \mathrm{H}_{4} \mathrm{D}_{2}$, and $\mathrm{C}_{3} \mathrm{H}_{5} \mathrm{D}$ from the $[\mathrm{M}+\mathrm{D}]^{+}$ions of the $\mathrm{C}_{6} \mathrm{H}_{5} \mathrm{OCH}_{2} \mathrm{CD}_{2} \mathrm{CH}_{3}$ ether can be estimated with the same approach as described in the text for the corresponding ions of the unlabeled phenyl $n$-propyl ether. The analysis is based upon the same assumptions and contributions of ring- and oxygen-deuteronated species in the propene loss; that is, $25 \%$ of the total population of the $[\mathrm{M}+\mathrm{D}]^{+}$ions has the deuterium atom at the oxygen atom, $25 \%$ at the 4 position of the ring, and $50 \%$ at the 2 or 6 position (see also Scheme I). For the oxygen-deuteronated $\mathrm{C}_{6} \mathrm{H}_{5} \mathrm{OCH}_{2} \mathrm{CD}_{2} \mathrm{CH}_{3}$ ether, the first step in the reaction sequence is the formation of a $\left[\mathrm{C}_{6} \mathrm{H}_{5} \mathrm{OD}^{+} \mathrm{CD}\left(\mathrm{CH}_{2} \mathrm{D}\right) \mathrm{CH}_{3}\right]$ complex that reacts further by $\mathrm{H}^{+}$or $\mathrm{D}^{+}$transfer to form the complexes $\left[\mathrm{C}_{6} \mathrm{H}_{5} \mathrm{OHD}^{+} \mathrm{CH}_{2}=\mathrm{CDCH}_{2} \mathrm{D}\right]$ and $\left[\mathrm{C}_{6} \mathrm{H}_{5} \mathrm{OD}_{2}^{+} \mathrm{CH}_{2}=\mathrm{CDCH}_{3}\right]$, respectively. If isotope effects are neglected, these complexes are formed in an abundance ratio $5 / 6: 1 / 6$. The former complex is assumed to react further by $\mathrm{H}^{+}$and $\mathrm{D}^{+}$transfer in a ratio $1: 1$, whereas the second complex undergoes only $\mathrm{D}^{+}$transfer. The complexes thus formed are considered to react further by $\mathrm{H}^{+}$and $\mathrm{D}^{+}$transfer that involve only the methyl groups of the secondary carbenium ions. The $\mathrm{H}^{+}$and $\mathrm{D}^{+}$transfers for each complex are assumed to occur without isotope effects and in a statistical ratio as indicated. The species thus formed are considered to dissociate without undergoing an additional $\mathrm{H}^{+}$or $\mathrm{D}^{+}$transfer to the propene molecule in the complex.
The combination of statistical factors for the various individual steps leads to the overall predicted relative importances for the losses of $\mathrm{C}_{3} \mathrm{H}_{3} \mathrm{D}_{3}, \mathrm{C}_{3} \mathrm{H}_{4} \mathrm{D}_{2}$, and $\mathrm{C}_{3} \mathrm{H}_{5} \mathrm{D}$. For the loss of $\mathrm{C}_{3} \mathrm{H}_{3} \mathrm{D}_{3}$ the overall statistical value is $20 / 72(5 / 6 \times 1 / 2 \times 4 / 6)$, whereas the value for $\mathrm{C}_{3} \mathrm{H}_{4} \mathrm{D}_{2}$ loss is $45 / 72(5 / 6 \times 1 / 2 \times 2 / 6+5 / 6 \times$ $1 / 2 \times 5 / 6+1 / 6 \times 2 / 2 \times 5 / 6)$ and for $\mathrm{C}_{3} \mathrm{H}_{5} \mathrm{D}$ the value becomes $7 / 72(5 / 6 \times 1 / 2 \times 1 / 6+1 / 6 \times 2 / 2$ $\times 1 / 6)$. In terms of percentages the predicted relative importance of the losses of $\mathrm{C}_{3} \mathrm{H}_{3} \mathrm{D}_{3}, \mathrm{C}_{3} \mathrm{H}_{4} \mathrm{D}_{2}$, and $\mathrm{C}_{3} \mathrm{H}_{5} \mathrm{D}$ from the oxygen-deuteronated species are 27.8 , 62.5 , and $9.7 \%$, respectively.

For the ions formed by deuteron transfer to the ring, these are considered to expel only $\mathrm{C}_{3} \mathrm{H}_{4} \mathrm{D}_{2}$ and $\mathrm{C}_{3} \mathrm{H}_{5} \mathrm{D}$ (see also Scheme III). The initial step in propene loss from these ions is the formation of a $\left[\mathrm{C}_{6} \mathrm{H}_{5} \mathrm{DO}^{+} \mathrm{CD}\left(\mathrm{CH}_{2} \mathrm{D}\right) \mathrm{CH}_{3}\right]$ complex that is assumed to react further by irreversible $\mathrm{H}^{+}$or $\mathrm{D}^{+}$transfer prior to dissociation. If isotope effects are neglected, this leads to a predicted ratio of $5 / 6: 1 / 6$ for the losses of $\mathrm{C}_{3} \mathrm{H}_{4} \mathrm{D}_{2}$ and $\mathrm{C}_{3} \mathrm{H}_{5} \mathrm{D}$ from the ring-deuteronated species. In terms of percentages, the relative importance of these losses by initial deuteron transfer to the ring becomes 83 and $17 \%$, respectively. With the assumed extent of deuteron transfer to the oxygen atom (25\%) and to the ring (75\%), the final relative importances of the losses of $\mathrm{C}_{3} \mathrm{H}_{3} \mathrm{D}_{3}, \mathrm{C}_{3} \mathrm{H}_{4} \mathrm{D}_{2}$, and $\mathrm{C}_{3} \mathrm{H}_{5} \mathrm{D}$ from the $[\mathrm{M}+\mathrm{D}]^{+}$ions of the $\mathrm{C}_{6} \mathrm{H}_{5} \mathrm{OCH}_{2} \mathrm{CD}_{2} \mathrm{CH}_{3}$ ether are estimated to be 7,77 , and $16 \%$, respectively.

The statistical analysis for the losses $\mathrm{C}_{3} \mathrm{H}_{3} \mathrm{D}_{3}$, $\mathrm{C}_{3} \mathrm{H}_{4} \mathrm{D}_{2}$, and $\mathrm{C}_{3} \mathrm{H}_{5} \mathrm{D}$ from the $[M+D]^{+}$ions of the methyl-substitute ethers labeled with two deuterium atoms at the $n$-propyl group follows the same procedure with the exception that the initial relative importance of deuteron transfer to the ring and the oxygen atom is changed according to the position and number of methyl groups as indicated in Table 5 and in the text.

\section{References}

1. Harrison, A. G. Chemical Ionization Mass Spectrometry; CRC Press: Boca Raton, 1992.

2. Kuck, D. Mass Spectrom. Rev. 1990, 9, 583.

3. Martinsen, D. P.; Buttrill, S. E., Jr. Org. Mass Spectrom. 1976, 11, 762.

4. Pollack, S. K,; Devlin, J. L., III; Summerhays, K. D.; Taft, R. W.; Hehre, W. J. J. Am. Chem. Soc. 1977, 99, 4583.

5. Hartman, K. G.; Lias, S. G. Int. I. Mass Spectrom. Ion Phys. $1978,28,213$.

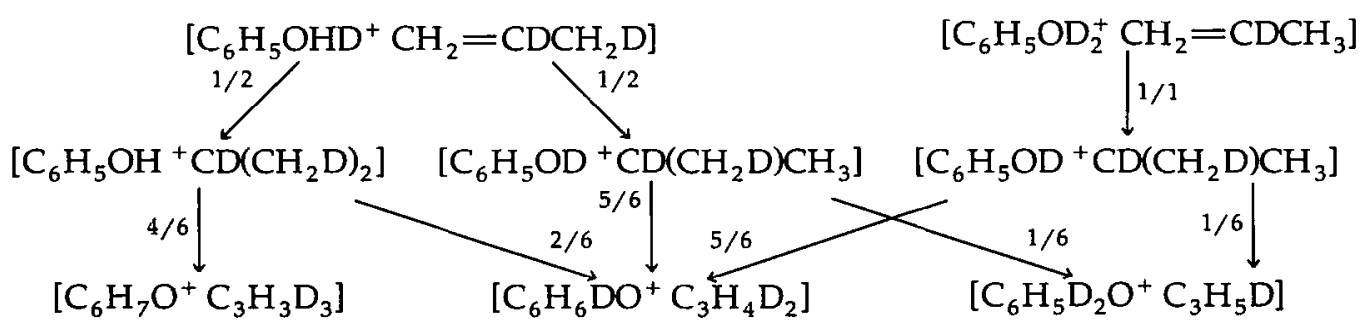


6. Lau, Y. K.; Nishizawa, K.; Tse, A.; Brown, R. S.; Kebarle, P. J. Am. Chem. Soc. 1981, 103, 6291.

7. Liauw, W. G.; Harrison, A. G. Org. Mass. Spectrom. 1981, 16, 388.

8. Mason, R. D.; Bohme, D. K.; Jennings, K. R. J. Chem. Soc. Faraday Trans. I 1982, 78, 1943.

9. Wood, K. V.; Burinsky, D. J.; Cameron, D.; Cooks, R. G. J. Org. Chem. 1983, 48, 5236.

10. Kingston, E. E.; Beynon, J. H.; Liehr, J. G.; Meyrant, P.; Flammang, R.; Maquestiau, A. Org. Mass Spectrom. 1985, 20. 351.

11. van der Wel, H.; Nibbering, N. M. M.; Kingston, E. E.; Beynon, J. H. Org. Mass Spectrom. 1985, 20, 535.

12. Mason, R.; Milton, D.; Harris, F. J. Chem. Soc. Chem. Commun. 1987, 1453.

13. McMahon, A. W.; Chadikun, F.; Harrison, A. G.; March, R. E. Int. J. Mass Spectrom. Ion Processes 1989, 87, 275.

14. Wincel, H.; Fokkens, R. H.; Nibbering, N. M. M. J. Am. Soc. Mass Spectrom. 1990 1, 225.

15. Hrušák, J.; Schröder, D.; Weiske, T.; Schwarz, H. I. Am. Chem. Soc. 1993, 115, 2015.

16. Tkaczyk, M.; Harrison, A. G. Int. J. Mass Spectrom. Ion Processes 1994, 132, 73.

17. Taft, R. W. In Proton Transfer Reactions; Caldin, E. F.; Gold, V., Eds.; Chapman and Hall: London, 1975.

18. Wolf, J. F.; Staley, R. H.; Koppel, I.; Taagepera, M.; McIver, R. T., Jr.; Beauchamp, J. L.; Taft, R. W. J. Am. Chem. Soc. 1977, 99, 5417.

19. Aue, D. H.; Bowers, M. T. In Gas Phase Ion Chemistry, Vol. 2; Bowers, M. T., Ed.; Academic Press: New York, 1979; p 2.

20. Taft, R. W. Prog. Phys. Org. Chem. 1983, 14, 247.

21. Szulejko, J. E.; McMahon, T. B. J. Am. Chem. Soc. 1993, 115, 7839 .

22. Jasinski, J. M.; Brauman, J. I. J. Am. Chem. Soc. 1980, 102, 2906.

23. Lias, S. G. Lecture Notes in Chemistry 1982, 31, 409.

24. Büker, H.-H.; Grützmacher, H.-F. Int. I. Mass Spectrom. Ion Processes 1991, 109, 95.
25. Meot-Ner (Mautner), M.; Sieck, W. L. J. Am. Chem. Soc. 1991, $113,4448$.

26. Vulpius, T.; Hammerum, S.; Houriet, R. Adv. Mass Spectrom. $1989,11,578$

27. Hunt, D.; Sethi, S. K. J. Am. Chem. Soc. 1980, 102, 6953.

28. Nakata, H.; Suzuki, Y.; Shibata, M.; Takahashi, K.; Konishi, H.; Takeda, N.; Tatematsu, A. Org. Mass Spectrom. 1990, 25, 649.

29. Nakata, H. Org. Mass Spectrom. 1992, 27, 686.

30. Nakata, H.; Kadoguchi, K.; Konishi, H.; Takeda, N.; Tatematsu, A. Org. Mass Spectrom. 1993, 28, 67.

31. Benoit, F. M.; Harrison, A. G. Org. Mass Spectrom. 1976, 11 599.

32. Kondrat, R. W.; Morton, T. H. J. Org. Chem. 1991, 56, 952.

33. Kondrat, R. W.; Morton, T. H. Org. Mass Spectrom. 1991, 26, 410.

34. Koch, W.; Liu, B.; Schleyer, P. v. R. J. Am. Chem. Soc. 1989, $111,3479$.

35. Morton, T. H. Tetrahedron 1982, 38, 3195.

36. McAdoo, D. J. Mass Spectrom. Rev. 1988, 7, 363.

37. Lias, S. G.; Bartmess, J. E.; Liebman, J. F.; Holmes, J. L.; Levin, R. D.; Mallard, W. G. J. Phys. Chem. Ref. Data 1988, 17, Suppl. 1.

38. Cooks, R. G.; Beynon, J. H.; Caprioli, R. M.; Lester, G. R. Metastable Ions; Elsevier: Amsterdam, 1973.

39. Harrison, A. G.; Mercer, R. S.; Reiner, E. J.; Young, A. B.; Boyd, R. K.; March, R. E.; Porter, C. J. Int. J. Mass Spectrom. Ion Processes 1986, 74, 13.

40. Zappey, H. W.; Ingemann, S.; Nibbering, N. M. M. J. Am. Soc. Mass Spectrom. 1992, 3, 515

41. Vogel, A. I. Vogel's Textbook of Practical Organic Chemistry, 5th ed.; Longman: Harlow, 1989.

42. Catalán, J.; Yáñez, M. J. Am. Chem. Soc. 1979, 101, 3490

43. DeFrees, D. J.; McIver, R. T., Jr.; Hehre, W. J. J. Am. Chem. Soc. 1977, 99, 3853.

44. Mautner, M. J. Phys. Chem. 1980, 84, 2716.

45. Harrison, A. G. Org. Mass Spectrom. 1987, 22, 637.

46. Bowen, R. D. Org. Mass Spectrom. 1993, 28, 1577. 